\title{
Solid Acid Hydrolysis for Isolation of Cellulose Nanocrystals and Chitin Nanocrystals - A mini review
}

\author{
Frederikus Tunjung Seta ${ }^{1,2, *}$, Xingye An ${ }^{2}$, Hongbin Liu ${ }^{2}$ \\ ${ }^{1}$ Balai Besar Pulp dan Kertas, Jl. Raya Dayeuhkolot No.132 Bandung, Indonesia \\ ${ }^{2}$ Tianjin University of Science and Technology, No.13 Ave, Binhai, Tianjin, China
}

Diterima : 6 Desember 2021, Revisi akhir : 21 Desember 2021, Disetujui terbit : 30 Desember 2021

\section{Hidrolisis Asam Padat untuk Isolasi Selulosa Nanokristal dan Kitin Nanokristal - mini reviu}

\begin{abstract}
Abstrak
Selulosa dan kitin adalah dua biopolimer yang mempunyai ketersediaan paling melimpah di bumi. Kedua material ini telah menarik banyak minat dari banyak peneliti, terutama terkait dengan bentuk nanopartikelnya. Metode untuk mengekstrak menjadi bahan berskala nano sebagian besar dengan hidrolisis mineral atau asam cair, seperti asam sulfat dan asam klorida. Meskipun menghasilkan rendemen yang tinggi, terdapat banyak kerugian saat proses ekstraksi, seperti stabilitas termal rendah dan sulit untuk dimodifikasi gugus fungsinya karena adanya gugus sulfat, memiliki kecenderungan untuk teragregasi untuk hidrolisis dengan asam klorida, potensi degradasi selulosa yang berlebihan; adanya efluen dalam jumlah besar yang dihasilkan pada tahap netralisasi, dan adanya bahaya korosi pada peralatan dan lingkungan. Kelemahan-kelemahan tersebut dapat digunakan asam padat untuk isolasi selulosa nanokristal (CNC) dan kitin nanokristal (ChNC). Kemampuannya untuk mengkristal kembali dan dapat dihasilkan kembali membuat asam padat lebih ramah lingkungan. Kelebihan lainnya adalah sebagian besar asam dapat mengesterifikasi permukaan selulosa dan kitin, sehingga sangat layak untuk digunakan pada proses hidrolisis CNC dan ChNC. Tujuan dari makalah ini adalah untuk memberikan tinjauan kritis tentang kemajuan terkini terkait hidrolisis asam padat karena memiliki karakteristik yang menarik bahkan beberapa sifatnya lebih baik daripada metode konvensional.
\end{abstract}

Kata kunci: selulosa nanokristal (CNC), kitin nanokristal (ChNC), hidrolisis asam padat, esterifikasi

\begin{abstract}
Cellulose and chitin are two of the most abundant biopolymers on earth. These two materials have attracted a lot of interest from many researchers, especially related to the shape of the nanoparticles. Recently the method to extract them into nanoscale materials mostly by mineral or liquid acid hydrolysis, such as sulfuric and hydrochloric acid. Despite their high yield production, many disadvantages are produced by their use as a hydrolysis catalyst, such as low thermal stability and are difficult to be functionalized due to the presence of sulfate groups, tendency to be aggregated due to the bare surface charge density for hydrochloric acid hydrolysis, the potential excessive degradation of cellulose; and large amounts of effluent will be produced due to the neutralization stage and corrosion hazards to the equipment and environment. To overcome the drawback of those acids, solid acid can be used to produce cellulose (CNC) and chitin nanocrystals (ChNC). Its ability to re-crystallize and be regenerated makes it more environmentally friendly. Another advantage is that most of the acids can esterify the surface of cellulose and chitin which makes solid acids very suitable for use in $\mathrm{CNC}$ and $\mathrm{ChNC}$ hydrolysis processes. The purpose of this paper is to provide a critical review on recent progress related to solid acid hydrolysis since they have interesting characteristics even some of their attribute is better than the conventional method.
\end{abstract}

Keywords: cellulose nanocrystals (CNC), chitin nanocrystals (ChNC), solid acid hydrolysis, esterification 


\section{Introduction}

Nanomaterials, with any nanoscale outer dimensions, or with nanoscale internal or surface structures has already become a prominent area due to their unique physical and chemicals properties resulting in improved performance and characteristics of final products in numerous enduser industries (Inshakova and Inshakov, 2017). Nanomaterials from bio-based resources have received a great deal of research interest in recent years as they are very likely to produce high-quality products with less environmental impact. The study of nanomaterials is not only about its extraction, but also the new applications in various fields. Among the nanomaterials, Cellulose Nanocrystals (CNC) and Chitin Nanocrystals (ChNC) are the most common representatives, which are green and sustainable nanomaterials derived from the natural most widely biomass. The type of nanomaterials extracted is determined by the processing methods: most of $\mathrm{CNC}$ and $\mathrm{ChNC}$ are extracted by chemical treatments, and cellulose nanofibrils (CNF) and chitin nanofibrils (CNF) are produced by mechanical or chemical treatments. The dimension and crystallinity of $\mathrm{CNC}$ and $\mathrm{CNF}$ or $\mathrm{ChNC}$ and $\mathrm{ChNF}$ are the main differentiators. Most CNF and ChNF shape consist of mixtures of amorphous and crystalline cellulose chains with a length of up to several microns, while $\mathrm{CNC}$ and $\mathrm{ChNC}$ are highly crystalline shape with a length typically less than $500 \mathrm{~nm}$ (Moon et al., 2011).

From a top-down perspective, cellulose and chitin contain crystalline and amorphous structures. These structures were formed by the aggregation of each of the structure chains via intra- and intermolecular hydrogen bonding. The crystalline phase of cellulose (CNC) and chitin (ChNC) can be separated from its amorphous phase by acid hydrolysis (Chen et al., 2017). Both of the crystalline structures have been applied in the fields of pharmaceutical and biomedical engineering, food, sensor, paper and packaging, optical and electronic devices, and many more (Huang et al., 2013; Jung et al., 2015; Gopi et al., 2017; Salaberria et al., 2017). Many researchers have been used the mineral acid hydrolysis method to extract crystalline parts because this method has the highest yield compared to other methods such as mechanical treatment and enzymatic hydrolysis (Moon et al., 2011; Song et al., 2018). The mechanical method maybe can produce a $100 \%$ yield, but this method is not a selective method, it means both of the crystalline and amorph regions will be affected by the mechanical force, moreover a lot of CNF will be formed during the process (Trache et al., 2017; Xie et al., 2018). The main shortcomings of this method are the potential excessive degradation of initial material, large amounts of effluent released from the neutralization stage process, and corrosion hazards of high concentration of strong acid to the equipment and environment (Chen, Xiaoquan Deng, Xueyan Shen, Wenhao, 2012; Amin et al., 2015; Zhang, Tsuzuki and Wang, 2015). As an alternative, solid acids can be used to hydrolyze chitin and cellulose for sugar production with the advantage of easing acid recovery and the hydrolyzed materials can be functionalized with carboxyl groups (Chen et al., 2016).

Many reviews summarized their source, chemistry, and applications of cellulose and chitin nanocrystals (Habibi, Lucia and Rojas, 2010; Duran, Paula Lemes and B. Seabra, 2011; Zeng et al., 2012; Wan and Tai, 2013; Abdul Khalil et al., 2016; Trache et al., 2017; Xie et al., 2018), but from our best knowledge, no review has been reported focused on the use of solid acid to prepare chitin and cellulose nanocrystals. The present review mainly focuses on the advances in preparation, properties, and potential application of $\mathrm{CNC}$ and $\mathrm{ChNC}$ by solid acid hydrolysis.

\section{The Structure and Extraction Method of Cellulose and Chitin Nanocrystals}

The structures of chitin and cellulose are very similar. Both are biological carrier and supporting materials in living plants and animals that grow in size from simple molecules in the nanometer range and composites in the micrometer range from highly crystalline fibrils (Fan, Saito and Isogai, 2008).

Cellulose, the most abundant biopolymer on earth have been attracted many researchers and industrial players in recent decades because of their excellent low toxicity, low density, biocompatibility, and biodegradability for numerous utilizations (Kargarzadeh et al., 2018). The term "cellulose" and its molecular formula $\left(\mathrm{C}_{6} \mathrm{H}_{10} \mathrm{O}_{5}\right)$ was first used in 1839 by Anselme Payen (Klemm et al., 2005). It can not only be separated from many biomass resources such as wood, cotton, hemp, and other plant-based materials, but cellulose can also be synthesized by algae, tunicates, and some bacteria (Henriksson et al., 2007; Iwamoto, Nakagaito and Yano, 2007; Siró and Plackett, 2010).

Cellulose can be described as a long linear polymer chain of ringed glucose molecules consisting of 1,4-anhydro-D-glucopyranose units and has a flat ribbon-like conformation (Siqueira, Bras and Dufresne, 2010; Dufresne, 2013). 
Cellulose plays an important role in abundant organic raw materials. It can be used for different purposes all over the world in different stages including paper, composites, constructions, additives, pharmaceutics, coatings, and many more (Li et al., 2013; Lee et al., 2014; Seabra et al., 2018; Awang et al., 2019; Lu et al., 2019). The market demand for industry-based cellulose reached almost 350 million tons in 2013 and continues to grow by $2.7 \%$ a year.

Cellulose can be distinguished into four different polymorphs, those are cellulose I, II, III, and IV as shown in Figure 1. In its natural form, cellulose can be found both in the crystalline and amorphous phases of cellulose I. Infra-red spectroscopy and $\mathrm{x}$-ray diffraction studies of cellulose organization in plants have shown that the crystalline regions have a bigger portion than the amorphous regions (Kroschwitz, 1985). The amorphous regions have lower density compared to crystalline regions and are easily available for bonding with other molecules, e.g. water. With the appropriate chemical hydrolysis method, cellulose microcrystals or nanocrystals $(\mathrm{CMC} / \mathrm{CNC})$ can be extracted from cellulose fibers. Meanwhile, if we use a mechanical method to handle cellulose fibers, mainly we could get micro or nano-fibrillated cellulose (CMF/CNF) (Siqueira, Bras and Dufresne, 2010). Cellulose II, or regenerated cellulose, is the most stable crystalline form obtained by regeneration of cellulose I with a strong alkali. The stable feature of cellulose II is mainly because of additional hydrogen bond per glucose residue and antiparallel layout atoms compare to cellulose I which has atoms direction in parallel shape (Saxena and Brown, 2005; Aulin et al., 2009). Cellulose III is obtained by ammonia treatment of cellulose I and II, meanwhile, cellulose IV is produced by heating modification of cellulose III (Aulin et al., 2009). Figure 2 shows the basic chemical structure of cellulose, showing that a dimer called cellobiose appears as repeating segments. One monomer of cellulose contains three hydroxyl groups and these groups have the ability to form

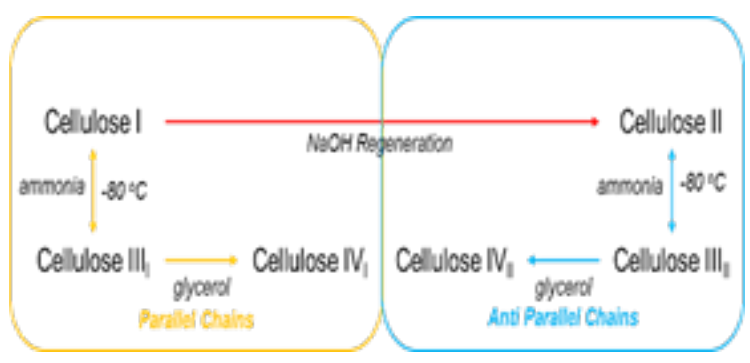

Figure 1. Polymorphs of cellulose (Panić et al., 2013) strong hydrogen bonds. Hydrogen bonds together with van der Waals forces form the basic cellulose fibers (Klemm et al., 2011; Ng et al., 2015).

After cellulose, chitin is the second most common biopolymer on the planet and is obtained from crab, shrimp, and lobster shell has been attracted wide usability due to the presence of the acetamido group on the second carbon of the pyranose ring (Barikani et al., 2014; Salaberria et al., 2017). As shown in Figure 3, Structure of chitin is a linear polysaccharide containing $\beta-(1,4)$ 2-deoxy-2-acetamido-D-glucopyranose repeating unit (Goodrich, J. D.; Winter, 2007). An acetamido group (-NHAc) instead of a hydroxyl group at the C-2 positions of chitin distinguished chitin and cellulose (Duan et al., 2018).

Chitin or poly $(\beta-(1 \rightarrow 4)-\mathrm{N}$-acetyl-Dglucosamine) was first proposed by Odier in 1823 as a material for insect cuticles. It kept its structure in outer shape after several treatments with a hot potassium hydroxide solution (Rudall and Kenchington, 1973). Chitin can be synthesized from many living organisms and in its natural form. Chitin is composed as structured crystalline microfibrils that form main structural components in the exoskeleton of arthropods or in the cell walls of fungi and yeast (Rinaudo, 2006). The degree of acetylation (DA) of chitin is typically around 0.90 , indicating the presence of large amounts of 2-acetamido-2-deoxy-d-glucopyranose, which contributes to the presents of antimicrobial activity (Salaberria et al., 2015; B. Duan et al., 2018).

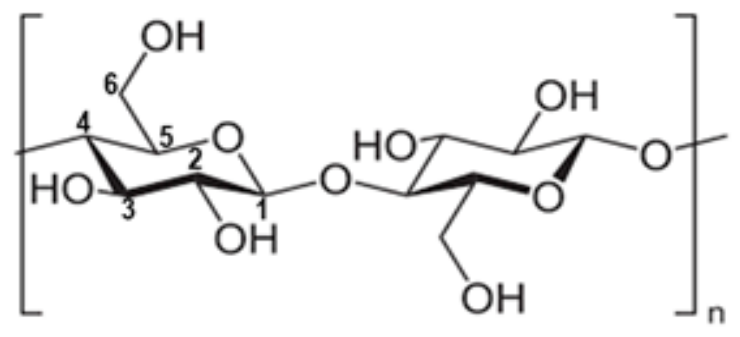

Figure 2. Molecular structure of cellulose ( $n=D P$, degree of polymerization) (Visanko, 2015)

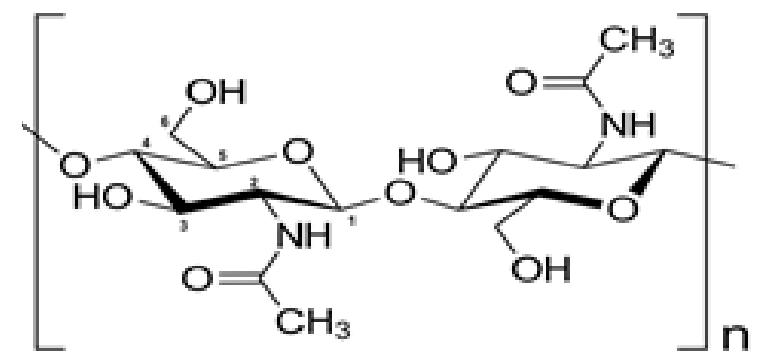

Figure 3. Molecular structure of chitin (Rodríguez et al., 1989) 
The crystalline phase, depending on its source, of chitin can be differentiated into $\alpha, \beta$, and $\gamma$ forms. All of them are assembled by the H-bonds network which controls the solubility, swelling, and reactivity (Younes and Rinaudo, 2015). The chain structure of $\alpha$-chitin is arranged alternately antiparallel, meanwhile, they are all parallel in $\beta$-chitin, and for the $\gamma$-chitin, it can be shown that two chains run in one direction and another chain runs in the opposite direction (Sugiyama et al., 1999; Jang et al., 2004). The $\alpha$-chitin occurs mainly in arthropods, fungi, and the cysts of Entamoeba, $\beta$-chitin is obtained from the pen of the Loligo squid, $\gamma$-Chitin exists in cocoon fibers of the Ptinus beetle and the stomach of Loligo (Jose and Alfredo, 1999).

$\alpha$-chitin has strong hydrogen bonding between its layers, while $\beta$-chitin has weak intrasheet hydrogen bonding. That is the reason for $\alpha$-chitin has lower reactivity and dissolves in various solvents compare to $\beta$-chitin (Kurita et al., 1993, 1994). For $\gamma$-chitin since Rudal and Kenchington (1973) proposed the invention, only a few investigations have focused on $\gamma$ - chitin because of the unusual nature of the raw material. Kaya et al., (2017) extract chitin from cocoon of the moth (Orgyia dubia) and they found that $\gamma$-chitin has different physicochemical characteristics, yet closer in structure to $\alpha$-chitin than $\beta$-chitin.

Renewable polysaccharides such as cellulose and chitin which are composed of crystalline and amorphous domains are candidates for organic nanoscale materials. The amorphous domains can be eliminated under certain methods such as acid hydrolysis, allowing the crystalline domains with high modulus can be extracted in nanoscale. The resulting nanocrystals can be used for many purposes such as nanocomposite, drug delivery system, waste removal, etc.

Cellulose nanocrystals are nanoparticles that can be derived from many sources such as, cotton (Sun et al., 2016; Chen et al., 2019; Ling et al., 2019), wood (Beck-candanedo, Roman and Gray, 2005; Filson and Dawson-Andoh, 2009; Abushammala, Krossing and Laborie, 2015; Miao et al., 2016), bamboo (Brito et al., 2012; Yu et al., 2012; Cao and Liu, 2015; Hong, Chen and Xue, 2016), tunicate (Zhao et al., 2015; Cao et al., 2017; Tang et al., 2017), wheat straw (Oun and Rhim, 2016; Liu et al., 2019), corn (Huang et al., 2017; Liu et al., 2019), fruits (Chieng et al., 2017; Trilokesh and Uppuluri, 2019), and ramie (Grishkewich et al., 2017; Kusmono, Wildan and Ilman, 2019). The origin of cellulose will determine the dimensions of CNC. For example, $\mathrm{CNC}$ derived from hardwood possess a dimension of 3 - $5 \mathrm{~nm}$ in diameter and $100-300$ $\mathrm{nm}$ in length, whereas $\mathrm{CNC}$ extracted from tunicate have a lateral and length dimension of $15-30 \mathrm{~nm}$ and $1000-1500 \mathrm{~nm}$ respectively (Elazzouzi-Hafraoui et al., 2008; Peng et al., 2011). Meanwhile, chitin nanocrystals can result from many resources such as crab (Gopalan Nair and Dufresne, 2003; Kiruba et al., 2011), shrimp (Einbu, 2007; Goodrich, J. D.; Winter, 2007), squid (Kurita et al., 1994), and riftia (Morin and Dufresne, 2002; Perrin et al., 2014), each of them has a different dimension in the range of $10-50 \mathrm{~nm}$ in diameter and $150-2200$ $\mathrm{nm}$ in length (Paillet and Dufresne, 2001; Morin and Dufresne, 2002; Lu, Weng and Zhang, 2004; Phongying, Aiba and Chirachanchai, 2007). The first method for preparing a suspension of chitin nanocrystals happened in 1959 by Marchessault et al (Marchessault, Morehead and Walter, 1959). In this process, $20 \mathrm{~g}$ of purified chitin was refluxed in a $2.5 \mathrm{~N}$ hydrochloric acid $(\mathrm{HCl})$ solution for 1 hour, and the resulting hydrolyzed chitin was dispersed in rod-shaped particles and concentrated in the liquid crystal phase.

In recent years, several methods have been investigated for the isolation of $\mathrm{CNC}$ and $\mathrm{ChNC}$, they are, chemical acid hydrolysis (Lahiji et al., 2010; Li-rong et al., 2011; Wang et al., 2012; Yu et al., 2013; Liu et al., 2018; Xie et al., 2019), enzymatic hydrolysis (Chen et al., 2012; Xu et al., 2013; Anderson et al., 2014), mechanical refining (Amin et al., 2015; Y. Li et al., 2016), ionic liquid treatment (Tan et al., 2015), subcritical water hydrolysis (Novo et al., 2016), oxidation method (Fan, Saito and Isogai, 2008; Visanko et al., 2014; Istomina et al., 2019) and combined processes ( $\mathrm{Li}$, Wang and Liu, 2011; Phanthong et al., 2015; An et al., 2016; Jiang et al., 2018; Seta et al., 2020). Among those processes, acid hydrolysis is the most commonly used to produce nanomaterials, especially ChNC (Moon et al., 2011; Zeng et al., 2012) because of their simplicity, high crystallinity product, and high yield ability. Theoretically, acid aqueous solutions can hydrolyze the amorphous and crystalline domains of polysaccharides structures. The main function of acid catalysis during $\mathrm{CNC}$ and $\mathrm{ChNC}$ production is to hydrolyze and release the amorphous structure. This acid hydrolysis process will release hydronium ions for hydrolytic cleavage of glycosidic bonds in cellulose molecular chains within amorphous regions along the cellulose fibrils (Ng et al., 2015).

As shown in Figure 4 and Figure 5 The main principle for making nanocrystals of chitin and cellulose is based on the different kinetics of hydrolysis between them and the acid. Acid concentration and hydrolysis time are the most 
important factors in determining the particle size and yield of nanocrystals. The swelling and hydrolysis of the amorphous phase occur much faster than the crystalline phase due to the periodic proximity of the molecular chains within the crystalline domain. This is why controlling hydrolysis variables is so important to produce nanocrystals of the desired dimensions and good yield (Zeng et al., 2012). The shape of the particles, the degree of crystallinity, and the size of the crystalline fibers depend on the natural source of the material and the method of extraction.

Mineral acid hydrolysis is one of the early developed and widely used to isolate and prepare $\mathrm{CNCs}$ and ChNCs. At present, primarily mineral acids, such as sulfuric acid for CNC and hydrochloric acid for ChNC are usually used for the isolation nanocrystals. Sulfuric acid is the most typically used to extract CNC. In recent years a lot of articles have been published from 2010-2020 as we can see from Table 1. Regarding the market visibility to fulfill larger quantities of industrial needs, sulfuric acid is more suitable than hydrochloric acid. In 2008, sulfuric acid was the most widely produced chemical in the United States, almost 10 times more than hydrochloric acid (Börjesson and Westman, 2015). Sulfuric acid produces a negative surface charge on the particles, leading to a more stable suspension. In general, the hydrolysis process requires a sulfuric acid concentration of $60-65 \%$,

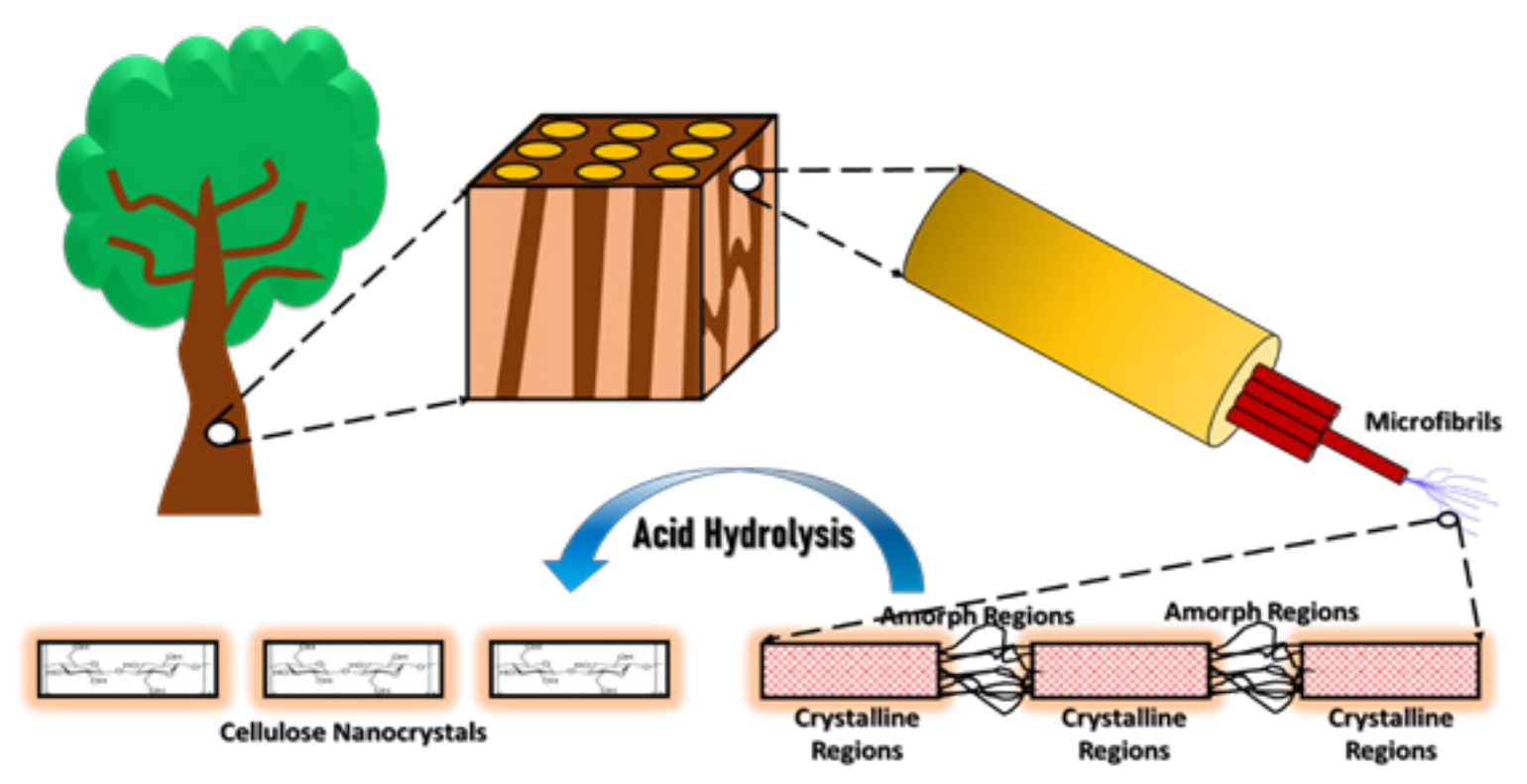

Figure 4. Schematic illustration for the preparation process of cellulose nanocrystals (CNC)

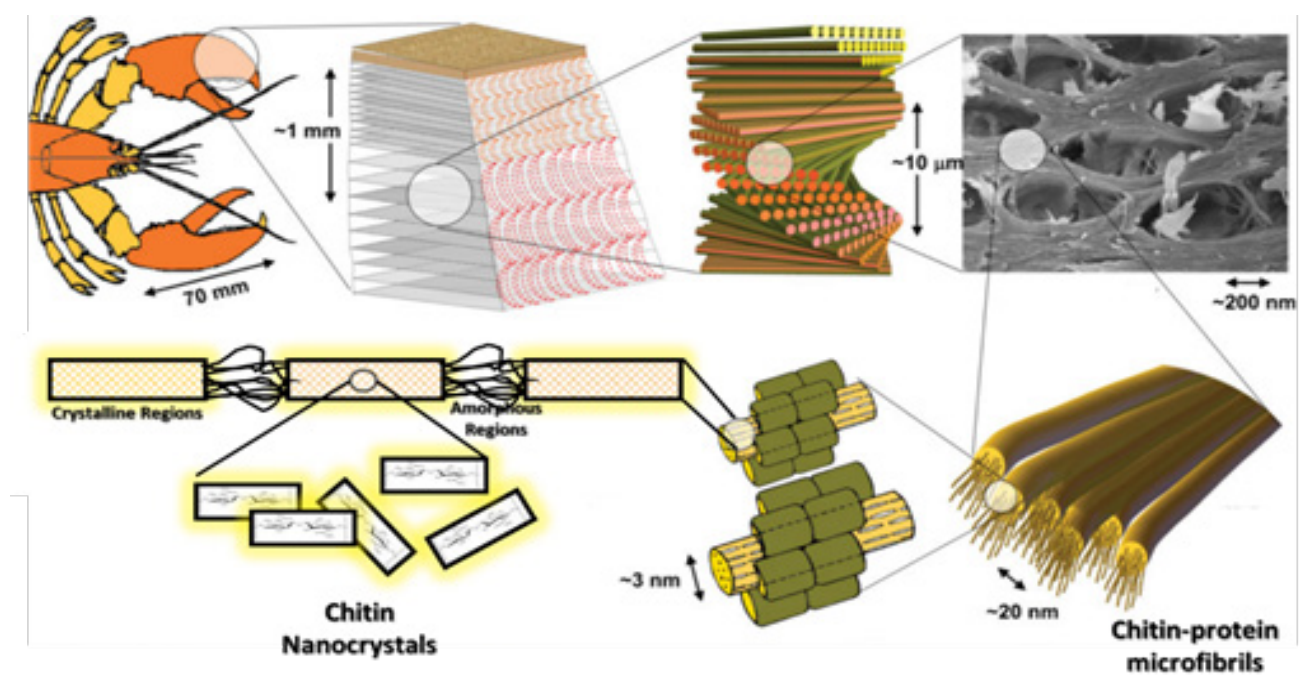

Figure 5. Schematic illustration for the extraction method of chitin nanocrystals (ChNC) (Nikolov et al., 2010) 
a reaction temperature of $40-50^{\circ} \mathrm{C}$, and a reaction time of 30-60 minutes. Some of those research results are shown in Table $\mathbf{1}$.

Unlike sulfuric acid hydrolysis, a lot of publications used hydrochloric acid to extract chitin nanocrystals. Meanwhile, many researchers prefer to use sulfuric acid than hydrochloric acid because this acid can make CNC very easy to be agglomerated in an aqueous system, because of the presence of less negative charge groups on its surface (Shang et al., 2019). Hydrochloric acid has a high ability to swell chitin and cellulose, making it easier to break intramolecular and intermolecular hydrogen bonds in the crystalline region. Some of the researches that used this acid can be seen in Table 2 .

\section{The CNC and ChNC isolation derived from different solid acid hydrolysis}

Despite the advantages of liquid and mineral acid hydrolysis, there are some drawbacks of this acid hydrolysis, are 1) it has low thermal stability and is difficult to be functionalized due to the presence of sulfate groups (for sulfuric acid-induced nanomaterials); 2) it tends to be aggregated due to the bare surface charge density (for hydrochloric acid-induced nanomaterials) (Yu et al., 2013); 3) the potential excessive degradation of cellulose; and 4) large amounts of effluent will be produced due to the neutralization stage and corrosion hazards to the equipment and environment (Chen et al., 2016). To overcome these problems, solid acid instead of liquid acid can be used as a catalyst in the hydrolysis process considering its advantages: 1) highly safe for the storage; 2) low transportation cost; 3) more environmentally friendly; 4) caused less corrosion to process equipment; and 5) possible surface modification during hydrolysis (Yeganeh, Behrooz and Rahimi, 2017; Seta et al., 2020). Some of the solid acids such as oxalic, maleic, and phosphotungstic have been reported can be used to produce nanomaterials. Most of the acids have the advantage of donating carboxylic structure and stability, the mechanism of the hydrolysis according to the structure is 1) maleic acid molecules react with $\beta$-1,4-glucosidic linkages/hydrogen bonds between anhydroglucose units in cellulose and chitin chains and release small and uniform particle size; 2) the acid can hydrolyze the disordered regions of materials to release the crystalline region; and 3) the acid can catalyze the esterification process of hydroxyl groups on the exposed chains and produce carboxylated $\mathrm{CNC}$ and $\mathrm{ChNC}$.

Table 1. Cellulose and chitin nanocrystals prepared by sulfuric acid hydrolysis from different origins

\begin{tabular}{|c|c|c|c|}
\hline Nanomaterials & Raw Materials & Conditions & References \\
\hline \multirow{8}{*}{$\mathrm{CNC}$} & Soy hulls & $\begin{array}{l}40^{\circ} \mathrm{C}, 30 \text { or } 40 \text { minutes, } \\
\mathrm{H}_{2} \mathrm{SO}_{4} 64 \%\end{array}$ & Flauzino Neto et al. (2013) \\
\hline & $\begin{array}{l}\text { Tea Leaf Waste } \\
\text { Fibers }\end{array}$ & $45^{\circ} \mathrm{C}, 45$ minutes, $\mathrm{H}_{2} \mathrm{SO}_{4} 65 \%$ & Rahman et al. (2017) \\
\hline & Jackfruit peel & $37^{\circ} \mathrm{C}, 1$ hour, $\mathrm{H}_{2} \mathrm{SO}_{4} 65 \%$ & Trilokesh and Uppuluri (2019) \\
\hline & $\begin{array}{l}\text { Cotton/ } \\
\text { Cotton Linter }\end{array}$ & $\begin{array}{l}45-55^{\circ} \mathrm{C}, 5-25 \text { minutes, } \\
\mathrm{H}_{2} \mathrm{SO}_{4} 50-64 \%\end{array}$ & $\begin{array}{l}\text { Chang et al. (2010); Morais et al. (2013); } \\
\text { Sun et al. (2016); Csiszár and Nagy } \\
\text { (2017) }\end{array}$ \\
\hline & Flax & $\begin{array}{l}45^{\circ} \mathrm{C} ; 25,240 \text { minutes, } \\
\mathrm{H}_{2} \mathrm{SO}_{4} 64 \%\end{array}$ & $\begin{array}{l}\text { Cao et al. (2008, 2013); Csiszár and } \\
\text { Nagy (2017) }\end{array}$ \\
\hline & Wood & $\begin{array}{l}35-80^{\circ} \mathrm{C}, 30-240 \text { minutes, } \\
\mathrm{H}_{2} \mathrm{SO}_{4} 46-68.4 \%\end{array}$ & $\begin{array}{l}\text { Bondeson, Mathew and Oksman (2006); } \\
\text { Durán et al. (2011); Wang, Zhao and Zhu, } \\
\text { (2014); Beltramino et al. (2016); Dong, } \\
\text { Bortner and Roman (2016); Lin, Enomae } \\
\text { and Chang (2019); Kandhola et al. (2020) }\end{array}$ \\
\hline & Sisal Fibers & $45^{\circ} \mathrm{C}, 30$ minutes, $\mathrm{H}_{2} \mathrm{SO}_{4} 60 \%$ & Morán et al. (2008) \\
\hline & Bamboo & $\begin{array}{l}30-60^{\circ} \mathrm{C}, 12-120 \text { minutes, } \\
\mathrm{H}_{2} \mathrm{SO}_{4} 45-75 \%\end{array}$ & $\begin{array}{l}\text { Brito et al. (2012); Yu et al. (2012); Chen } \\
\text { et al. (2013); Hong, Chen and Xue (2016; } \\
\text { Wijaya et al. (2019) }\end{array}$ \\
\hline \multirow{3}{*}{$\mathrm{ChNC}$} & Crab Shell & $60^{\circ} \mathrm{C}, 60$ minutes, $\mathrm{H}_{2} \mathrm{SO}_{4} 64 \%$ & Oun and Rhim (2018) \\
\hline & Shrimp Shell & $\begin{array}{l}60-100^{\circ} \mathrm{C}, 90-180 \text { minutes, } \\
\mathrm{H}_{2} \mathrm{SO}_{4} 64 \%\end{array}$ & Gopi et al. (2017); Oun and Rhim, (2020) \\
\hline & Lobster Shell & $60^{\circ} \mathrm{C}, 90$ minutes, $\mathrm{H}_{2} \mathrm{SO}_{4} 64 \%$ & Li et al. (2016) \\
\hline
\end{tabular}


Table 2. Cellulose and chitin nanocrystals prepared by hydrochloric acid hydrolysis from different resources

\begin{tabular}{|c|c|c|c|}
\hline Nanomaterials & Raw Materials & Conditions & References \\
\hline \multirow{5}{*}{$\mathrm{CNC}$} & Wheat Straw & 24 hours, $\mathrm{HCl} 32 \%$ & Huntley et al. (2015) \\
\hline & $\begin{array}{l}\text { Cotton/ } \\
\text { Cotton Linter }\end{array}$ & 12 hours, $\mathrm{HCl} 35 \%$ & Lorenz et al. (2017) \\
\hline & Wood & $\begin{array}{l}110^{\circ} \mathrm{C}, 90-180 \text { minutes, } \\
\mathrm{HCl} 37 \%\end{array}$ & Cheng et al., 2017; Shang et al. (2019) \\
\hline & Filter Paper & $110^{\circ} \mathrm{C}, 90$ minutes, $\mathrm{HCl} 37 \%$ & Boujemaoui et al. (2015) \\
\hline & Bamboo & $60^{\circ} \mathrm{C}, 120$ minutes, $\mathrm{HCl} 37 \%$ & Zhang et al. (2014) \\
\hline \multirow{5}{*}{$\mathrm{ChNC}$} & Crab Shell & $80-100^{\circ} \mathrm{C}, 90$ minutes, $\mathrm{HCl} 3 \mathrm{M}$ & $\begin{array}{l}\text { Gopalan Nair and Dufresne (2003); } \\
\text { Lu, Weng and Zhang, 2004; Tzoumaki, } \\
\text { Moschakis and Biliaderis (2010); Goetz } \\
\text { et al., (2016); Jalvo, Mathew and Rosal, } \\
\text { (2017) }\end{array}$ \\
\hline & Lobster Shell & $100 \mathrm{oC}, 90$ minutes, $\mathrm{HCl} 3 \mathrm{M}$ & Salaberria, Labidi and Fernandes (2014) \\
\hline & Shrimp Shell & $90-95^{\circ} \mathrm{C}, 90$ minutes, $\mathrm{HCl} 3 \mathrm{M}$ & $\begin{array}{l}\text { Goodrich and Winter (2007); Perrin et al. } \\
\text { (2014); Tzoumaki et al. (2015); Singh et } \\
\text { al. (2020) }\end{array}$ \\
\hline & Squid Pen & $90^{\circ} \mathrm{C}, 90$ minutes, $\mathrm{HCl} 3 \mathrm{M}$ & Paillet and Dufresne (2001) \\
\hline & Riftia Tubes & $90^{\circ} \mathrm{C}, 90$ minutes, $\mathrm{HCl} 3 \mathrm{M}$ & Morin and Dufresne (2002) \\
\hline
\end{tabular}

\section{Oxalic acid}

Oxalic acid is a dicarboxylic organic acid compound with the formula $\mathrm{C}_{2} \mathrm{H}_{2} \mathrm{O}_{4}$, which his appearance as a white crystalline solid and forms a colorless solution in water, because of its appearance some people call it "crab acid". It is an inexpensive chemical and can industrially be produced from plant-based resources and its melting point is around $104-106^{\circ} \mathrm{C}$. Oxalic acid is industrially produced in three main ways: oxidation of different agricultural carbohydrate waste products (corn cobs, sawdust, oat hulls, etc.); fermentation processes caused by by-products in citric acid production; and pyrolysis of inorganic formats. This dicarboxylic acid finds many uses in the textile and leather industries and as an intermediate in organic syntheses (Sneeden, 1982). They dissolve in from 8 to 11 parts of water at $15.5^{\circ} \mathrm{C}$ and completely dissolve in water at $100^{\circ} \mathrm{C}$ (Hussain, 2012).

\section{Oxalic acid hydrolysis for the isolation of CNC}

Chen et al (2016) used oxalic acid at a concentration of $50-70 \%$ and $90-120^{\circ} \mathrm{C}$ for the first time to produce cellulose nanocrystals from bleached eucalyptus kraft pulp. The CNC has good dispersion and contains carboxylic acid group content of about $0.1-0.4 \mathrm{mmol} / \mathrm{g}$. Thermal degradation temperature until $\mathrm{CNC}$ can reach $322^{\circ} \mathrm{C}$. The crystallinity index
(CrI) was approximately $81 \%$. The diameters of the CNC were approximately $15 \mathrm{~nm}$ and the shortest length was $273 \mathrm{~nm}$. Xu et al (2017) also used oxalic acid at concentration $0.11-1.11 \mathrm{~mol} / \mathrm{L}$ and hydrolysis temperature $80-100^{\circ} \mathrm{C}$ to hydrolyzed bleached birch kraft pulp. The resulted yield was about $85 \%$. Maximum thermal degradation was $355^{\circ} \mathrm{C}$, higher than $\mathrm{CNC}$ made by sulfuric acid hydrolysis $\left(200^{\circ} \mathrm{C}\right)$. The obtained diameter was 8-15 nm, length 200-1200 nm, and carboxylic groups content was $0.1-0.3 \mathrm{mmol} / \mathrm{g}$. The route of $\mathrm{ChNC}$ and $\mathrm{CNC}$ made by oxalic acid hydrolysis can be seen in Figure 6(a) and the resulted CNC and ChNC in Figure 6(b) and Figure 6(c).

$\mathrm{Li}$ et al (2017) used softwood dissolving pulp and mixed it with oxalic acid at $110^{\circ} \mathrm{C}$ for about 15-120 minutes resulted $\mathrm{CNC}$ which has an average length of 150-220 nm and a width of 16-20 nm. Interestingly the yield of this method with 30 minutes hydrolysis time could reach 99\%. This result was very high indicated that the use of oxalic acid can be an effective catalyst to hydrolyze cellulose into CNC. Figure 6(e) shows one of their research results was crossed polarized in an aqueous solution that can be used in the next nano-sized function. Another experiment was conducted by Xie et al (2019), they use bleached eucalyptus kraft pulp and mixed oxalic acid with sulfuric acid to reduce temperature $\left(80^{\circ} \mathrm{C}\right)$ and increase yield $(>70 \%)$. CNC has a diameter range 
of about 5-20 nm and a length of 150-400 nm. The use of sulfuric acid could be reduced from $55 \mathrm{~g} / \mathrm{g}$ CNC into $2.4 \mathrm{~g} / \mathrm{g} \mathrm{CNC}$ and $91 \pm 2 \%$ of oxalic acid can be reobtained by simple recrystallization. Song et al (2018) produced CNC by ball mill as a pretreatment before hydrolyzing cellulose in various concentrations of oxalic acid. The optimum yield $( \pm 60 \%)$ was obtained by $60 \%$ oxalic acid, $80^{\circ} \mathrm{C}$ hydrolysis temperature, and 4 hours hydrolysis time. This hybrid process could extract CNC with good properties, such as maximum degradation temperature of $332{ }^{\circ} \mathrm{C}, 300-400 \mathrm{~nm}$ in length, and crystallinity index around $70.7 \%$. Jia and Liu (2019) compared oxalic acid and sulfuric acid straightly. The filter paper was their raw material. The optimum condition of oxalic acid hydrolysis was $8.75 \%$ oxalic acid solution, reaction time 15 minutes, and temperature $110^{\circ} \mathrm{C}$. In this condition they can get $93.77 \%$ of yield and they reported that the result was higher than previous researches. The conclusions of their work were oxalic acid CNC and sulfuric acid $\mathrm{CNC}$ have similar basic structural properties, such as UV-Vis transmittance, average particle size, Zeta potential, and $\mathrm{Crl}$ value. But, as we can see in Figure 6(d), they also found that the brilliant snowflake-like pattern of $\mathrm{CNC}$ film was observed through oxalic acid instead of sulfuric acid, and carboxylated $\mathrm{CNC}$ produced with oxalic acid easily forms a liquid crystal phase. Moreover, they suggested potential application prospects in optical devices and chiral separation according to its CNC properties.

Jia et al. (2017) compared three different raw materials and reacted with this dicarboxylic acid. They were used bleached eucalyptus pulp (BEP), spruce dissolving pulp (SDP), and cotton-based qualitative filter paper (QFP) as their raw research materials. The highest yield obtained by QFP (5.81\%) with $50 \%$ oxalic acid solution was used at $100^{\circ} \mathrm{C}$, $300 \mathrm{rpm}$, and 1 hour reaction time. The same group tried to increase the yield by adding disk milling (DM) pretreatment of bleached kraft eucalyptus pulp (Jia, Bian, et al., 2017). They succeed increased it from $5 \%$ to $35 \%$ as shown in Figure 6(f). The $\mathrm{CNC}$ was applied as film and 3D printed patterns. The prepared film produced via hybrid DM-oxalic

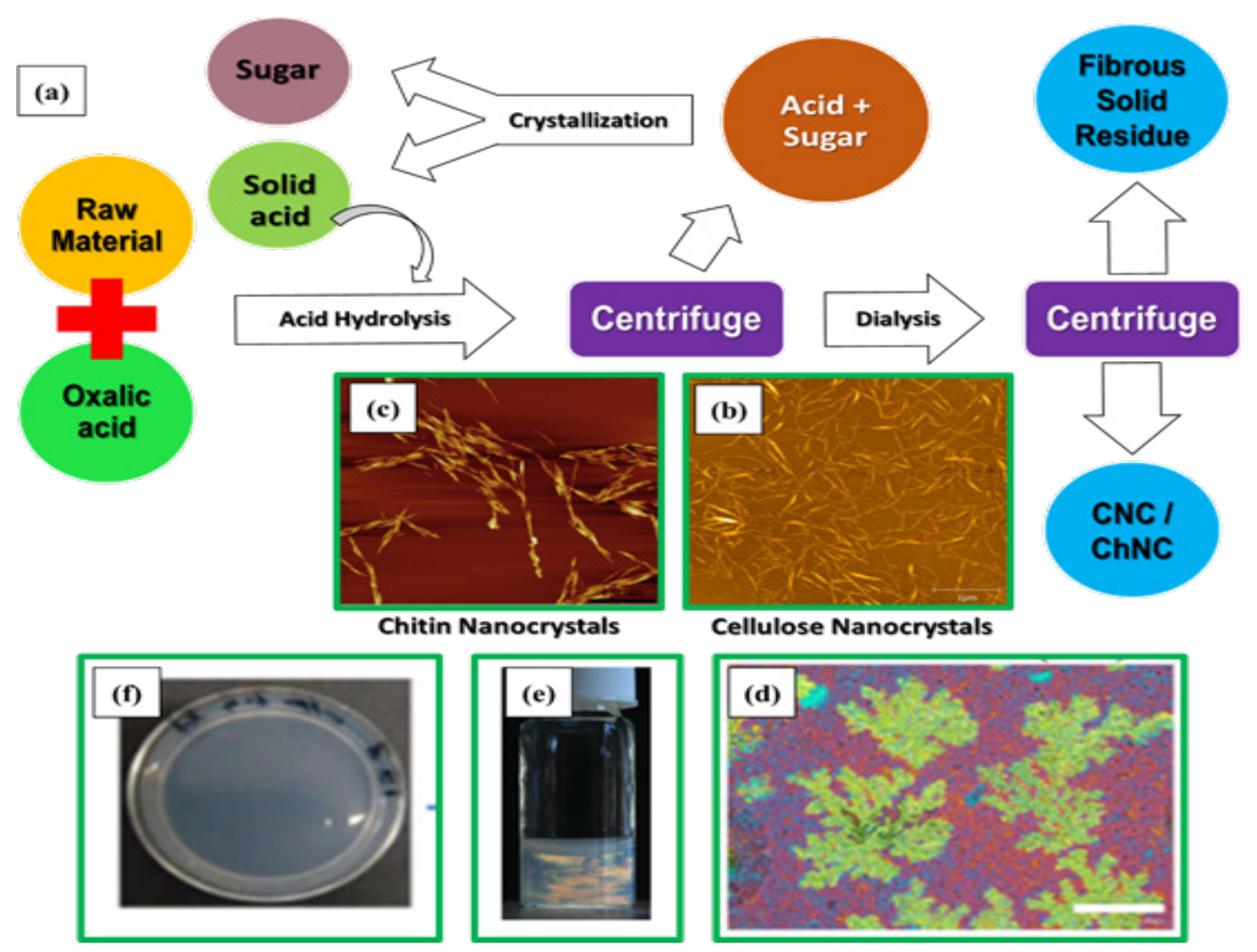

Figure 6. (a) Schematic diagram of oxalic acid hydrolysis (Chen et al., 2016) (b) AFM Image of CNC (Chen et al., 2016) (c) AFM image of ChNC (Yuan et al., 2020) (d) POM images of CNC composite film (Jia and Liu, 2019) (e) A concentrated aqueous suspension of CNC observed between crossed polarizers (Li, Henschen and Ek, 2017) (f) The photo of CNC composite film (Jia, Chen, et al., 2017) 
acid method has very high transmittance and super low haze with great values of $90.6 \%$ and $6.6 \%$ at the wavelength of $600 \mathrm{~nm}$. The prepared film can hold and maintain its appearance without visible change at $150^{\circ} \mathrm{C}$ for 4 hours. This characterization makes it very promising as electronic devices fabrication. The resulting 3D printing with porous structures shown this material can be potentially applied in tissue engineering scaffolds.

\section{Oxalic acid hydrolysis for the isolation of $\mathrm{ChNC}$}

The use of oxalic acid to produce chitin nanocrystals was introduced by Yuan et al (2020). They mixed oxalic acid with choline chloride under mixing treatment at $100^{\circ} \mathrm{C}$ for 1 hour and 3 hours. The highest yield reached $79.5 \%$ and the morphology of ChNC was $530 \pm 89 \mathrm{~nm}$ in length and $49 \pm 8 \mathrm{~nm}$ in diameter. The crystallinity index could reach $90.09 \%$ and the temperature at maximum degradation was $367.2^{\circ} \mathrm{C}$

\section{Phosphotungstic acid (PTA)}

Phosphotungstic acid (PTA) is odorless acid and one of the strongest heteropoly acids with the chemical formula $\mathrm{H}_{3} \mathrm{PW}_{12} \mathrm{O}_{40}$. Its melting point is $89^{\circ} \mathrm{C}$ and the solubility is $200 \mathrm{~g} / 100 \mathrm{ml}$ in water. As a heteropoly acid, PTA has some advantages, such as (1) high activity, thermal stability, and selectivity; (2) high solubility in polar solvents; (3) very high proton mobility of heteropolyacid anions (Qiang et al., 2016). Shimizu et al (2009) demonstrated that phosphotungstic acid has abundant Bronsted acid sites which can break the $\beta-1,4$-glycosidic bonds in cellulose and could hydrolyze cellulose into glucose.

The use of PTA as a chemical in cellulose hydrolysis introduced by Liu et al (2014). They used bleached hardwood pulp as raw material and 50-85\% of PTA mixture for 15-30 hours of hydrolysis time and $90^{\circ} \mathrm{C}$ of hydrolysis temperature. The optimum condition was obtained at $90^{\circ} \mathrm{C}$ for 30 hours by the use of $75 \%(\mathrm{w} / \mathrm{w})$ PTA, the dimension of rod-like CNC was $15-25 \mathrm{~nm}$ in width and $600-800 \mathrm{~nm}$ in length as shown in Figure 7(b). The crystalline index of CNC was $85 \%$ and maximum degradation has happened at $350^{\circ} \mathrm{C}$. In this experiment, they recycled the PTA residue after the hydrolysis process and after 5 cycles the yield of the $\mathrm{CNC}$ could reach $58 \%$, which was very close to the maximum yield of the regular process $(60 \%)$. A higher yield can be obtained to extract a larger dimension. Qian et al (2016) tried to extract microcrystalline cellulose (MCC) from eucalyptus kraft dissolving pulp. The MCC has yielded of around 93.62\%, length of $13.77-26.17 \mu \mathrm{m}$, and crystallinity of $76.37 \%$. They used $58 \%(\mathrm{w} / \mathrm{w}) \mathrm{HPW}$ catalyst and a solid-liquid radio of 1:40, under the reaction condition at $90{ }^{\circ} \mathrm{C}$ for about 2 hours. From both experiments, we can see that the reaction time and solid-liquid ratio of acid mixture very determined the resulting nanomaterials.

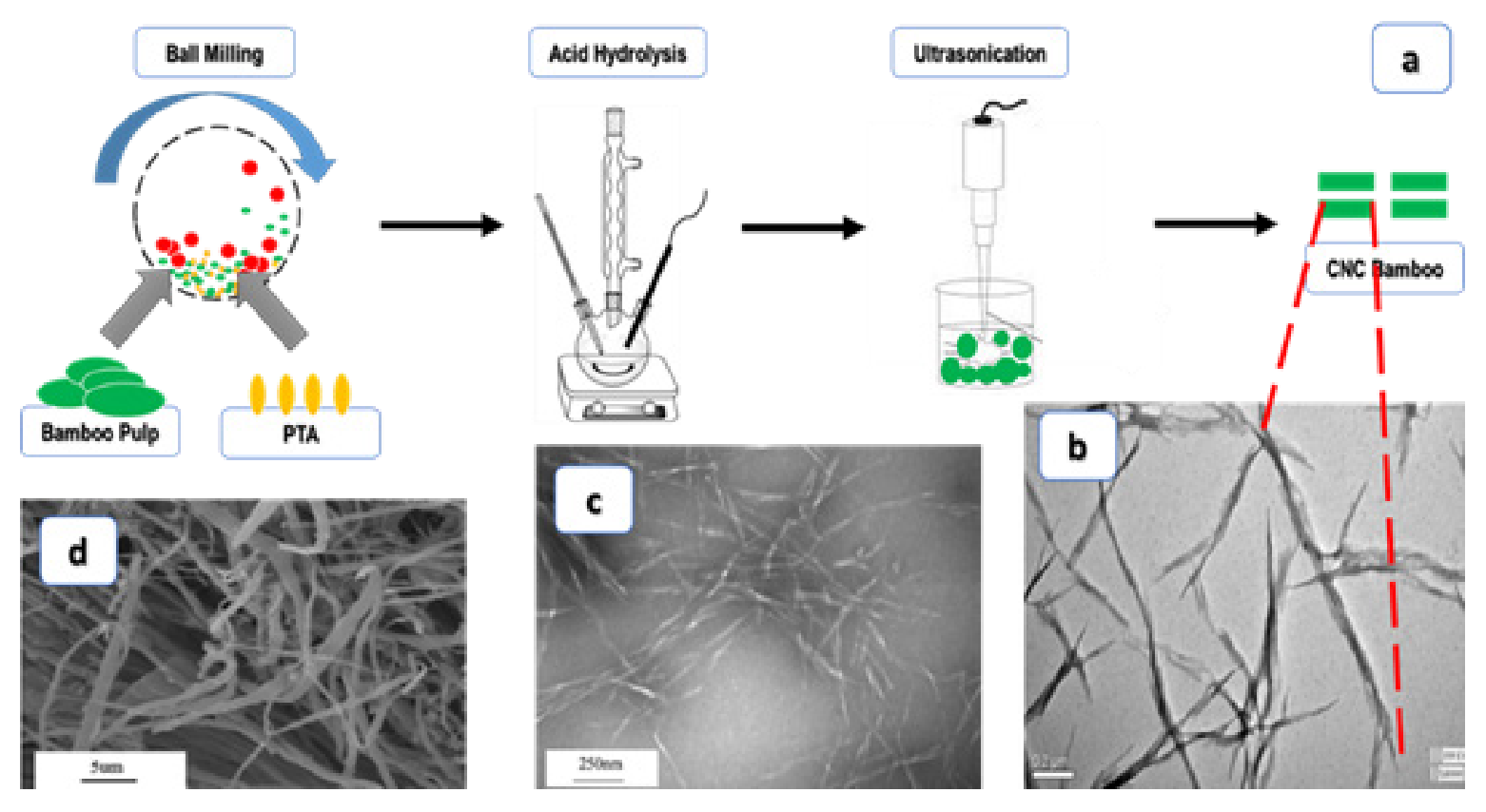

Figure 7. (a) Schematic diagram of phosphotungstic acid hydrolysis simultaneous mechanochemical activation (Lu et al., 2016) (b) AFM image of resulted CNC (Liu et al., 2014) (c) AFM image of resulted CNC (Lu et al., 2016) (d) SEM image of pristine bamboo (Lu et al., 2016) 
Lu et al (2016) used mechanochemical to extract $\mathrm{CNC}$ from bamboo pulp. From Figure 7(d), bamboo pulp along with $12.5 \%$ PTA solution were milled by 20,6 mm agate balls in an agate jar for 1.5-2.5 hours. Then, after removing agate balls from agate jar, the pulp and PTA solution were introduced into a roundbottomed flask which was kept the temperature at 90 ${ }^{\circ} \mathrm{C}$ in an oil bath for 4.5-5.5 hours. Phosphotungstic acid concentration of $13.5 \%$, reaction time of 4.7 hours, and ball milling time of 2.2 hours produced the optimum yield $(88.4 \%)$. Figure 7(a) show the route of the method and Figure 7(c) show the short rod-like cellulose nanocrystals obtained with the range of 200-300 nm in length and $25-50 \mathrm{~nm}$ in width. The crystallinity index reached $79.6 \%$ and the maximum degradation was $348^{\circ} \mathrm{C}$.

From those experiments, the use of a ball mill could assist in a shorter reaction time and increased yield. But the crystallinity index would be reduced. Ball mill treatment is known as a process that can decrease the crystalline structure of materials (Feng, Han and Owen, 2004).

\section{Citric acid}

This weak acid that occurs naturally in citrus fruits has the chemical formula $\mathrm{C}_{6} \mathrm{H}_{8} \mathrm{O}_{7}$. In biochemistry, it is an intermediate in the citric acid cycle, which occurs in the metabolism of all aerobic organisms. Its melting point at $156^{\circ} \mathrm{C}$ and its solubility in water could reach $84 \% \mathrm{w} / \mathrm{w}$ at $100^{\circ} \mathrm{C}$. The production of citric acid reaches more than two million tons per year to fulfill the raw material of acidifier, flavoring, and chelating agent industries (Apleblat, 2014).

The first use of citric acid to extract nanomaterials is carried out by Yu et al (2016). They produced $\mathrm{CNC}$ by citric acid/hydrochloric acid mixture and microcrystalline cellulose as the raw material. The resulting CNC has a rod-like shape with the size of $200-250 \mathrm{~nm}$ in length and $15-20 \mathrm{~nm}$ in width. Yield resulting from this mixture reached $89.5 \%$, highest crystallinity index was $91.4 \%$ and maximum thermal degradation was $377.9^{\circ} \mathrm{C}$. The same author also used the same raw material and acid mixture with the addition recycle citric acid as the variables. After two recycling processes, the resulting $\mathrm{CNC}$ still has a good yield, of which fresh citric acid was $87.8 \%$ and $86.5 \%$ after the second recycle. The morphological analyses also showed good results, where 220.8 $\pm 26.6 \mathrm{~nm}$ in length and $13.2 \pm 2.7 \mathrm{~nm}$ in diameter. Thermal degradation after the second process is also not so different which is $347.0^{\circ} \mathrm{C}$ compare to $357.5^{\circ} \mathrm{C}$ from its pristine citric acid (Yu et al., 2019).

\section{Maleic acid}

Maleic acid is an organic acid and has chemical formula $\mathrm{HO}_{2} \mathrm{CCH}=\mathrm{CHCO}_{2} \mathrm{H}$. From its structure, maleic acid has dicarboxylic acid structure, a molecule with two carboxyl groups. Maleic acid is an industrial raw material for the production of glyoxylic acid by ozonolysis and an adhesion promoter for different substrates, such as nylon and zinc coated metals. Maleic acid is high soluble in water $\left(78.8 \mathrm{~g}\right.$ per $100 \mathrm{ml}$ of water at $25^{\circ} \mathrm{C}$ and $392.6 \mathrm{~g}$ per $100 \mathrm{ml}$ of water at $97.5^{\circ} \mathrm{C}$ ) (BährleRapp, 2007) and its melting point $130-131^{\circ} \mathrm{C}$ (National Center for Biotechnology Information, 2020).

The first use of maleic acid as a catalyst to hydrolyzed cellulose was made by Mosier et al (2001). They used microcrystalline cellulose as a raw material and found that maleic acid could hydrolysis cellobiose with minimal glucose degradation. In 2008, Lu and Mosier (2008) hydrolyzed hemicellulose from corn stover to produced xylose. They found that $0.2 \mathrm{M}$ maleic acid can produce $80-90 \%$ xylose yields at reaction temperatures between 100 and $150^{\circ} \mathrm{C}$.

Wang et al (2017) used maleic acid to produce $\mathrm{CNC}$ and cellulose nanofibers (CNF) from bleached eucalyptus kraft pulp. The mean $\mathrm{CNC}$ length was around $450-650 \mathrm{~nm}$ and the aspect ratio was 60 and 90. The research group by Bian et al (2017a; 2017b) found that the yield of CNC by maleic acid hydrolysis was shown low number (around 6\%). The low strength of acid was the reason why they got that result. Instead of the low yield, maleic acid can produce $\mathrm{CNC}$ with good characteristics, such as good dispersibility (thanks to two carboxyl groups of maleic acid), can be recycled, and better dimension than $\mathrm{CNC}$ made by sulfuric acid hydrolysis (Yeganeh, Behrooz and Rahimi, 2017). Seta's research group tried to overcome the yield problem by combining ball mill method as a pretreatment before maleic acid hydrolysis as we can see in Figure 8(a). The ball mill treatment can open up the firm structure of bamboo pulp, thus maleic acid molecules are easier to react and extracted more CNC. The yield by this hybrid method could increase 10 times and reduce the length of the $\mathrm{CNC}$ as shown in Figure 8(b) (Seta et al., 2020). The resulting $\mathrm{CNC}$ also showed high colloidal stability after 5 days.

The work to produce ChNC from shrimp shells by maleic acid hydrolysis was worked by Yang's research group, they used hydrolysis temperature of $110^{\circ} \mathrm{C}, 3$ hours hydrolysis time, and $80 \%$ maleic 
acid. From Figure 8(c) and Figure 8(d) show the resulted $\mathrm{ChNC}$ to collaborate with sodium lignosulfonate and silver nanoparticles to carry out catalytic degradation performance for model contaminants of Congo Red (Yang et al., 2020). The result was very good and this nanohybrid particle can be potentially used in the wastewater field.

\section{Phosphoric acid}

With the chemical formula $\mathrm{H}_{3} \mathrm{PO}_{4}$, phosphoric acid is a weak acid and has the appearance of an $85 \%$ aqueous solution, which is a colorless, odorless, and non-volatile syrupy liquid. The route to make CNC using phosporic acid hydrolysis can be seen in Figure 9. The first CNC made by phosphoric acid

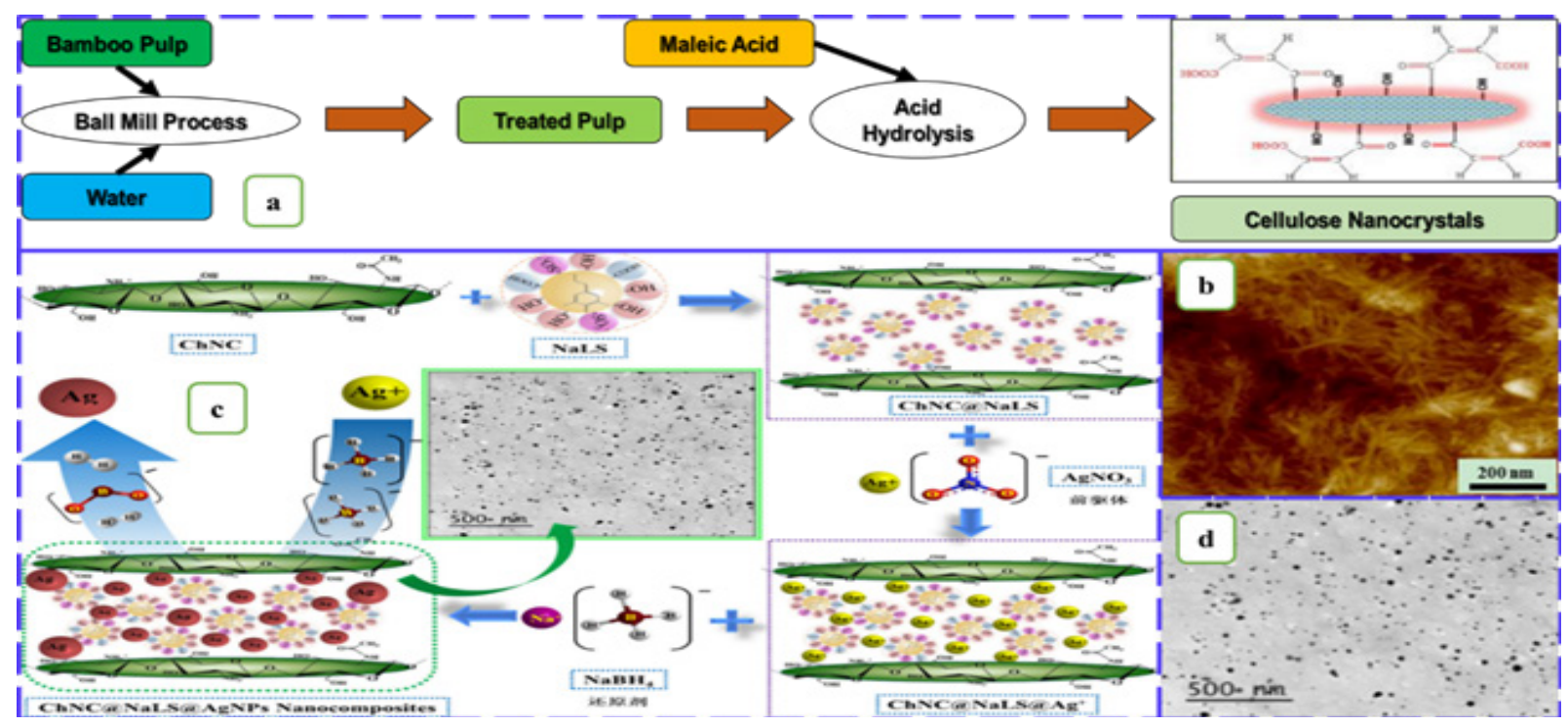

Figure 8. (a) Schematic diagram of ball mill pretreatment and maleic acid hydrolysis (Seta et al., 2020) (b) AFM Image of resulted CNC (Seta et al., 2020) (c) Schematic diagram of ChNC@NaLS@AgNPs nanocomposites (Yang et al., 2020) (d) TEM image of ChNC@NaLS@AgNPs nanocomposites (Yang et al., 2020)
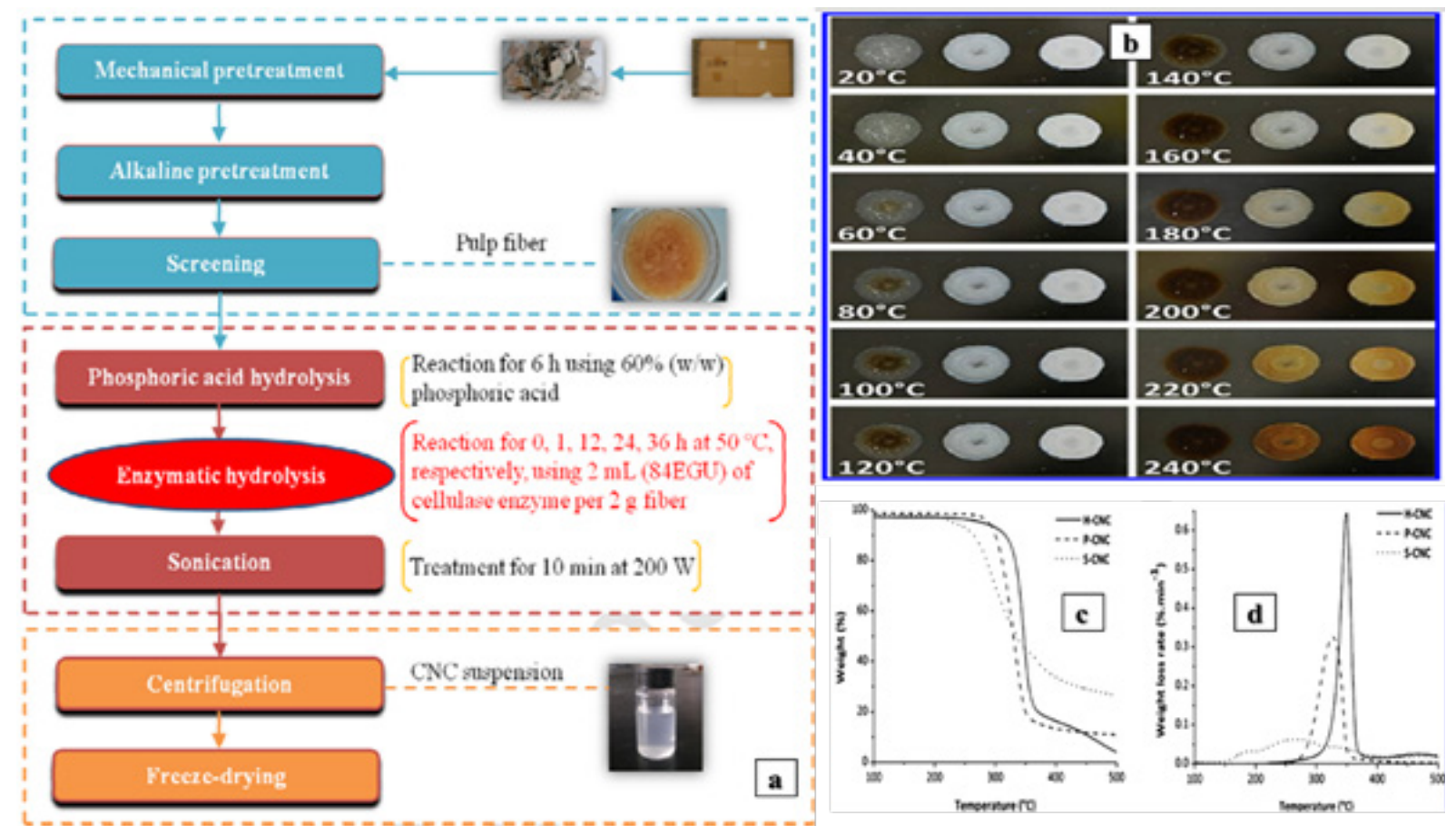

Figure 9. (a) Schematic diagram of phosphoric acid CNC made by hybrid method (Tang et al., 2015) (b) Photos of solution-cast samples of S-CNCs (left), P-CNCs (middle), and H-CNCs (right) (Espinosa et al., 2013) (c) TGA traces and (d) derivatives weight loss of CNC made by phosphoric, sulfuric and hydrochloric acid (Espinosa et al., 2013) 
hydrolysis was introduced by Lemke et al (2012). They used bleached western red cedar kraft pulp as the raw materials to study the phase structure but not the characterization of the CNC.

Espinosa et al (2013) use this acid to hydrolyze Whatman no. 1 fitter paper and characterized the resulted $\mathrm{CNC}$. They found that the $\mathrm{CNC}$ has length of $316 \pm 127 \mathrm{~nm}$, diameter of $31 \pm 14 \mathrm{~nm}$ for the condition of 90 minutes at $100{ }^{\circ} \mathrm{C}$ with an $\mathrm{H}_{3} \mathrm{PO}_{4}$ concentration of $10.7 \mathrm{M}$. Its crystallinity index reached $81 \%$ and the main concern of their research project was the thermal degradation of their $\mathrm{CNC}$ were reached $325^{\circ} \mathrm{C}$ as shown in Figure 9(c) and Figure 9(d). The yield reported was $76-80 \%$. They also compared three kinds of $\mathrm{CNC}$ (phosphoric, hydrochloric, and sulfuric acid $\mathrm{CNC}$ ), and they found that $\mathrm{CNC}$ made by hydrochloric acid has the best thermal stability among them and $\mathrm{CNC}$ made by sulfuric acid was the worst. The results of the thermal stability test of the $\mathrm{CNC}$ can be seen in Figure 9(b).

Another work by Tang et al (2015) shows in Figure 9(a) phosphoric acid can be used as a combined method to produce CNC. They used old corrugated containers (OCC) as their raw materials and combined enzymatic process, phosphoric hydrolysis, and mechanical method (sonication). Enzymatic hydrolysis and mechanical treatment in these works could enhance yield, crystallinity, and thermal stability. The hybrid methods also reduced the length of the resulting CNC. The yield was increased almost $100 \%$, crystallinity was increased from $54.3 \%$ to $57.8 \%$, and the thermal stability was increased from $276-312^{\circ} \mathrm{C}$.

\section{Conclusion and Future Perspectives}

As renewable and biodegradable biomaterials, chitin and cellulose are taking attraction and will continuously catch interest from both scientists and industry. Recent studies have mainly focused on the preparation of $\mathrm{CNC}$ and $\mathrm{ChNC}$ by liquid acid hydrolysis and less attention has been paid to the solid acid catalyst, especially for chitin nanoparticles. Solid acid hydrolysis is a promising method to extract $\mathrm{CNC}$ and $\mathrm{ChNC}$ from its natural resources. Many advantages can result from this method, especially the recycling ability and esterification during the hydrolysis process considering some of these acids have a dicarboxylic group. Many publications have been made for cellulose as the $\mathrm{CNC}$ raw materials by solid acid hydrolysis, but very few perspectives regarding chitin nanocrystals. This is an opportunity in the future to explore more about this material. Also, not so many applications of $\mathrm{CNC}$ and $\mathrm{ChNC}$ even though it has many positive characteristics. Despite the advantages, the major challenge for the preparation by solid acid hydrolysis is the low yield. To overcome this problem, hydrolysis needs to be combined with other methods, such as mechanical method, enzymatic process, or TEMPO-mediated oxidation process. These hybrid methods can deliver not only efficient preparation of nanocrystals based on targeted cleavage of certain bonds but also can give these polysaccharide-based nanocrystals to be more readily available and be used in broader fields and fulfill industrial feasibility.

\section{References}

Abdul Khalil, H. P. S., Saurabh, C. K., Adnan, A. S., Nurul Fazita, M. R., Syakir, M. I., Davoudpour, Y., Rafatullah, M., Abdullah, C. K., Haafiz, M. K. M. and Dungani, R. (2016) 'A review on chitosan-cellulose blends and nanocellulose reinforced chitosan biocomposites: Properties and their applications', Carbohydrate Polymers. 150, pp. 216-226. doi: 10.1016/j. carbpol.2016.05.028.

Abushammala, H., Krossing, I. and Laborie, M. P. (2015) 'Ionic liquid-mediated technology to produce cellulose nanocrystals directly from wood', Carbohydrate Polymers. 134, pp. 609-616. doi: 10.1016/j. carbpol.2015.07.079.

Amin, K. N., Annamalai, P. K., Morrow, I. C. and Martin, D. (2015) 'Production of cellulose nanocrystals via a scalable mechanical method', RSC Advances. Royal Society of Chemistry, 5(70), pp. 57133-57140. doi: 10.1039/ c5ra06862b.

An, X., Wen, Y., Cheng, D. and Zhu, X. (2016) 'Preparation of cellulose nano-crystals through a sequential process of cellulase pretreatment and acid hydrolysis', Cellulose. doi: 10.1007/s10570-016-0964-4.

Anderson, S. R., Esposito, D., Gillette, W., Zhu, J. Y., Baxa, U. and McNeil, S. E. (2014) 'Enzymatic preparation of nanocrystalline and microcrystalline cellulose', Tappi Journal, 13(5), pp. 35-42. doi: 10.32964/tj13.5.35.

Apleblat, A. (2014) Citric acid. Springer.

Aulin, C., Ahok, S., Josefsson, P., Nishino, T., Hirose, Y., Österberg, M. and Wågberg, L. (2009) 'Nanoscale cellulose films with different crystallinities and mesostructures - Their surface properties and interaction with water', Langmuir, 25(13), pp. 7675-7685. doi: 10.1021/ la900323n. 
Awang, N. W., Ramasamy, D., Kadirgama, K., Samykano, M., Najafi, G. and Sidik, N. A. C. (2019) 'An experimental study on characterization and properties of nano lubricant containing Cellulose Nanocrystal (CNC)', International Journal of Heat and Mass Transfer. , 130, pp. 1163-1169. doi: 10.1016/j.ijheatmasstransfer.2018.11.041.

Bährle-Rapp, M. (2007) 'Maleic Acid', in Springer Lexikon Kosmetik und Körperpflege. Berlin, Heidelberg: Springer Berlin Heidelberg, pp. 337337. doi: 10.1007/978-3-540-71095-0 6254.

Barikani, M., Oliaei, E., Seddiqi, H. and Honarkar, H. (2014) 'Preparation and application of chitin and its derivatives: A review', Iranian Polymer Journal (English Edition), 23(4), pp. 307-326. doi: 10.1007/s 13726-014-0225-z.

Beck-candanedo, S., Roman, M. and Gray, D. G. (2005) 'Effect of Reaction Conditions on the Properties and Behavior of Wood Cellulose Nanocrystal Suspensions', Biomacromolecules, 6, pp. 1048-1054.

Beltramino, F., Roncero, M. B., Torres, A. L., Vidal, T. and Valls, C. (2016) 'Optimization of sulfuric acid hydrolysis conditions for preparation of nanocrystalline cellulose from enzymatically pretreated fibers', Cellulose. Springer Netherlands, 23(3), pp. 1777-1789. doi: 10.1007/s 10570-016-0897-y.

Bian, H., Chen, L., Dai, H. and Zhu, J. Y. (2017) 'Integrated production of lignin containing cellulose nanocrystals (LCNC) and nanofibrils (LCNF) using an easily recyclable di-carboxylic acid', Carbohydrate Polymers. , 167, pp. 167176. doi: 10.1016/j.carbpol.2017.03.050.

Bian, H., Chen, L. and Dai, H. (2017) 'Effect of fiber drying on properties of lignin containing cellulose nanocrystals and nanofibrils produced through maleic acid hydrolysis', Cellulose. Springer Netherlands. doi: 10.1007/s10570017-1430-7.

Bondeson, D., Mathew, A. and Oksman, K. (2006) 'Optimization of the isolation of nanocrystals from microcrystalline cellulose by acid hydrolysis', Cellulose, 13(2), pp. 171-180. doi: 10.1007/s 10570-006-9061-4.

Börjesson, M. and Westman, G. (2015) 'Crystalline Nanocellulose - Preparation, Modification, and Properties', in Cellulose Fundamental Aspects and Current Trends. doi: 10.5772/61899.

Boujemaoui, A., Mongkhontreerat, S., Malmström, E. and Carlmark, A. (2015) 'Preparation and characterization of functionalized cellulose nanocrystals', Carbohydrate Polymers., 115, pp. 457-464. doi: 10.1016/j.carbpol.2014.08.110.
Brito, B. S. L., Pereira, F. V., Putaux, J. L. and Jean, B. (2012) 'Preparation, morphology and structure of cellulose nanocrystals from bamboo fibers', Cellulose, 19(5), pp. 1527-1536. doi: 10.1007/s 10570-012-9738-9.

Camarero Espinosa, S., Kuhnt, T., Foster, E. J. and Weder, C. (2013) 'Isolation of thermally stable cellulose nanocrystals by phosphoric acid hydrolysis', Biomacromolecules, 14(4), pp. 1223-1230. doi: 10.1021/bm400219u.

Cao, L., Yuan, D., Xu, C. and Chen, Y. (2017) 'Biobased, self-healable, high strength rubber with tunicate cellulose nanocrystals', Nanoscale, 9(40), pp. 15696-15706. doi: 10.1039/c7nr05011a.

Cao, X., Chen, Y., Chang, P. R., Muir, A. D. and Falk, G. (2008) 'Starch-based nanocomposites reinforced with flax cellulose nanocrystals', Express Polymer Letters, 2(7), pp. 502-510. doi: 10.3144/expresspolymlett.2008.60.

Cao, X., Xu, C., Wang, Y., Liu, Yu, Liu, Yuhong and Chen, Y. (2013) 'New nanocomposite materials reinforced with cellulose nanocrystals in nitrile rubber', Polymer Testing, 32(5), pp. 819-826. doi: 10.1016/j.polymertesting.2013.04.005.

Cao, X. and Liu, D. (2015) 'Preparation and characterization of bamboo nanocrystalline cellulose', (February). doi: 10.15376/ biores.7.2.1802-1812.

Chang, C. P., Wang, I. C., Hung, K. J. and Perng, Y. S. (2010) 'Preparation and characterization of nanocrystalline cellulose by acid hydrolysis of cotton linter', Taiwan Journal of Forest Science, 25(3), pp. 251-264. doi: 10.7075/ TJFS.201009.0251.

Chen, Xiaoquan Deng, Xueyan Shen, Wenhao, J. ilngling (2012) 'Controlled Enzymolysis Preparation of', BioResources, 7(3), pp. 42374248.

Chen, F., Hong, B., Guo, X. and Xue, G. X. (2013) 'Pretreatment of bamboo powder for cellulose nanocrystalline by sulfuric acid hydrolysis', Advanced Materials Research, 785-786, pp. 346-353. doi: 10.4028/www.scientific.net/ AMR.785-786.346.

Chen, J. H., Liu, J. G., Yuan, T. Q. and Sun, R. C. (2017) 'Comparison of cellulose and chitin nanocrystals for reinforcing regenerated cellulose fibers', Journal of Applied Polymer Science, 134(22), pp. 1-8. doi: 10.1002/app.44880.

Chen, L., Zhu, J. Y., Baez, C., Kitin, P. and Elder, T. (2016) 'Highly thermal-stable and functional cellulose nanocrystals and nanofibrils produced using fully recyclable organic acids', Green Chemistry, 18(13), pp. 3835-3843. doi: 10.1039/ c6gc00687f. 
Chen, X., Deng, X., Shen, W. and Jiang, L. (2012) 'Controlled enzymolysis preparation of nanocrystalline cellulose from pretreated cotton fibers', BioResources, 7(3), pp. 42374248. doi: 10.15376/biores.7.3.4237-4248.

Chen, X. Q., Pang, G. X., Shen, W. H., Tong, X. and Jia, M. Y. (2019) 'Preparation and characterization of the ribbon-like cellulose nanocrystals by the cellulase enzymolysis of cotton pulp fibers', Carbohydrate Polymers. 207, pp. 713-719. doi: 10.1016/j. carbpol.2018.12.042.

Cheng, M., Qin, Z., Chen, Y., Hu, S., Ren, Z. and Zhu, M. (2017) 'Efficient Extraction of Cellulose Nanocrystals through Hydrochloric Acid Hydrolysis Catalyzed by Inorganic Chlorides under Hydrothermal Conditions', ACS Sustainable Chemistry and Engineering, 5(6), pp. 4656-4664. doi: 10.1021/ acssuschemeng.6b03194.

Chieng, B. W., Lee, S. H., Ibrahim, N. A., Then, Y. Y. and Loo, Y. Y. (2017) 'Isolation and characterization of cellulose nanocrystals from oil palm mesocarp fiber', Polymers, 9(8), pp. 1-11. doi: 10.3390/polym9080355.

Csiszár, E. and Nagy, S. (2017) 'A comparative study on cellulose nanocrystals extracted from bleached cotton and flax and used for casting films with glycerol and sorbitol plasticisers', Carbohydrate Polymers., 174, pp. 740-749. doi: 10.1016/j.carbpol.2017.06.103.

Dong, S., Bortner, M. J. and Roman, M. (2016) 'Analysis of the sulfuric acid hydrolysis of wood pulp for cellulose nanocrystal production: A central composite design study', Industrial Crops and Products. 93, pp. 76-87. doi: 10.1016/j.indcrop.2016.01.048.

Duan, B., Huang, Y., Lu, A. and Zhang, L. (2018) 'Recent advances in chitin based materials constructed via physical methods', Progress in Polymer Science. 82, pp. 1-33. doi: 10.1016/j. progpolymsci.2018.04.001.

Duan, Y., Freyburger, A., Kunz, W. and Zollfrank, C. (2018) 'Cellulose and chitin composite materials from an ionic liquid and a green cosolvent', Carbohydrate Polymers. 192, pp. 159-165. doi: 10.1016/j.carbpol.2018.03.045.

Dufresne, A. (2013) Nanocellulose: from nature. to high performance tailored materials. Walter de Gruyter. https://doi. org/https://doi.org/10.1515/9783110254600o high performance tailored materials. Walter de Gruyter. doi: https://doi. org/10.1515/9783110254600.
Durán, N., Lemes, A. P., Durán, M., Freer, J. and Baeza, J. (2011) 'A minireview of cellulose nanocrystals and its potential integration as coproduct in bioethanol production', Journal of the Chilean Chemical Society, 56(2), pp. 672677. doi: $10.4067 / \mathrm{S} 0717-97072011000200011$.

Duran, N., Paula Lemes, A. and B. Seabra, A. (2011) 'Review of Cellulose Nanocrystals Patents: Preparation, Composites and General Applications', Recent Patents on Nanotechnology, 6(1), pp. 16-28. doi: $10.2174 / 187221012798109255$.

Einbu, A. (2007) Characterisation of chitin and a study of its acid-catalysed hydrolysis.

Elazzouzi-Hafraoui, S., Nishiyama, Y., Putaux, J. L., Heux, L., Dubreuil, F. and Rochas, C. (2008) 'The shape and size distribution of crystalline nanoparticles prepared by acid hydrolysis of native cellulose', Biomacromolecules, 9(1), pp. 57-65. doi: 10.1021/bm700769p.

Fan, Y., Saito, T. and Isogai, A. (2008) 'Chitin nanocrystals prepared by TEMPO-mediated oxidation of $\alpha$-chitin', Biomacromolecules, pp. 192-198. doi: 10.1021/bm700966g.

Feng, Y. T., Han, K. and Owen, D. R. J. (2004) 'Discrete element simulation of the dynamics of high energy planetary ball milling processes', Materials Science and Engineering A, 375377(1-2 SPEC. ISS.), pp. 815-819. doi: 10.1016/j.msea.2003.10.162.

Filson, P. B. and Dawson-Andoh, B.E.(2009) 'Sonochemical preparation of cellulose nanocrystals from lignocellulose derived materials', Bioresource Technology. 100(7), pp. 22592264. doi: 10.1016/j.biortech.2008.09.062.

Flauzino Neto, W. P., Silvério, H. A., Dantas, N. O. and Pasquini, D. (2013) 'Extraction and characterization of cellulose nanocrystals from agro-industrial residue - Soy hulls', Industrial Crops and Products. 42(1), pp. 480488. doi: 10.1016/j.indcrop.2012.06.041.

Goetz, L. A., Jalvo, B., Rosal, R. and Mathew, A. P. (2016) 'Superhydrophilic anti-fouling electrospun cellulose acetate membranes coated with chitin nanocrystals for water filtration', Journal of Membrane Science. 510, pp. 238-248. doi: 10.1016/j.memsci.2016.02.069.

Goodrich, J. D. and Winter, W. T. (2007) 'Alpha-chitin nanocrystals prepared from shrimp shells and their specific properties', Biomacromolecules, p. 252- 257.

Gopalan Nair, K. and Dufresne, A. (2003) 'Crab shell chitin whisker reinforced natural rubber nanocomposites. 1. Processing and swelling behavior', Biomacromolecules, 4(3), pp. 657665. doi: 10.1021/bm020127b. 
Gopi, S., Balakrishnan, P., Pius, A. and Thomas, S. (2017) 'Chitin nanowhisker (ChNW)functionalized electrospun PVDF membrane for enhanced removal of Indigo carmine', Carbohydrate Polymers. 165, pp. 115-122. doi: 10.1016/j.carbpol.2017.02.046.

Grishkewich, N., Mohammed, N., Tang, J. and Tam, K. C. (2017) 'Recent advances in the application of cellulose nanocrystals', Current Opinion in Colloid and Interface Science. 29, pp. 32-45. doi: 10.1016/j.cocis.2017.01.005.

Habibi, Y., Lucia, L. A. and Rojas, O. J. (2010) 'Cellulose nanocrystals: Chemistry, selfassembly, and applications', Chemical Reviews, 110(6), pp. 3479-3500. doi: 10.1021/cr900339w.

Henriksson, M., Henriksson, G., Berglund, L. A. and Lindström, T. (2007) 'An environmentally friendly method for enzyme-assisted preparation of microfibrillated cellulose (MFC) nanofibers', European Polymer Journal, 43(8), pp. 3434-3441. doi: 10.1016/j. eurpolymj.2007.05.038.

Hong, B., Chen, F. and Xue, G. (2016) 'Preparation and characterization of Cellulose nanocrystals from bamboo pulp', Cellulose Chemistry and Technology, 50(2), pp. 225-231.

Huang, J., Zhu, H., Chen, Y., Preston, C., Rohrbach, K., Cumings, J. and $\mathrm{Hu}$, L. (2013) 'Highly transparent and flexible nanopaper transistors', ACS Nano, pp. 2106-2113. doi: 10.1021/ nn304407r.

Huang, S., Zhou, L., Li, M. C., Wu, Q. and Zhou, D. (2017) 'Cellulose nanocrystals (CNCs) from corn stalk: Activation energy analysis', Materials, 10(1), pp. 1-13. doi: 10.3390/ ma10010080.

Huntley, C. J., Crews, K. D., Abdalla, M. A., Russell, A. E. and Curry, M. L. (2015) 'Influence of strong acid hydrolysis processing on the thermal stability and crystallinity of cellulose isolated from wheat straw', International Journal of Chemical Engineering, 2015. doi: $10.1155 / 2015 / 658163$.

Hussain, S. T. (2012) 'Solubility of Oxalic Acid', Asian Journal of Research in Chemistry, 5(11), pp. 1323-1330.

Inshakova, E. and Inshakov, O. (2017) 'World market for nanomaterials: Structure and trends', MATEC Web of Conferences, 129(2017), pp. 1-5. doi: 10.1051/ matecconf/201712902013.

Istomina, A. P., Bogdanova, O. I., Streltsov, D. R. and Chvalun, S. N. (2019) 'Stability of Suspensions of $\alpha$-Chitin Nanocrystals Obtained by TEMPO Oxidation', Polymer Science - Series A, pp. 589-597. doi: 10.1134/ S0965545X19050080.
Iwamoto, S., Nakagaito, A. N. and Yano, H. (2007) 'Nano-fibrillation of pulp fibers for the processing of transparent nanocomposites', Applied Physics A: Materials Science and Processing, 89(2), pp. 461-466. doi: 10.1007/ s00339-007-4175-6.

Jalvo, B., Mathew, A. P. and Rosal, R. (2017) 'Coaxial poly(lactic acid) electrospun composite membranes incorporating cellulose and chitin nanocrystals', Journal of Membrane Science. 544, pp. 261-271. doi: 10.1016/j. memsci.2017.09.033.

Jang, M. K., Kong, B. G., Jeong, Y. Il, Lee, C. H. and Nah, J. W. (2004) 'Physicochemical characterization of $\alpha$-chitin, $\beta$-chitin, and $\gamma$-chitin separated from natural resources', Journal of Polymer Science, Part A: Polymer Chemistry, pp. 3423-3432. doi: 10.1002/ pola.20176.

Jia, C., Bian, H., Gao, T., Jiang, F., Kierzewski, I. M., Wang, Y., Yao, Y., Chen, L., Shao, Z., Zhu, J. Y. and Hu, L. (2017) 'Thermally Stable Cellulose Nanocrystals toward High-Performance 2D and 3D Nanostructures', ACS Applied Materials and Interfaces, 9(34), pp. 28922-28929. doi: 10.1021/acsami.7b08760.

Jia, C., Chen, L., Shao, Z., Agarwal, U. P., Hu, L. and Zhu, J. Y. (2017) 'Using a fully recyclable dicarboxylic acid for producing dispersible and thermally stable cellulose nanomaterials from different cellulosic sources', Cellulose. Springer Netherlands, 24(6), pp. 2483-2498. doi: 10.1007/s10570-017-1277-y.

Jia, W. and Liu, Y. (2019) 'Two characteristic cellulose nanocrystals (CNCs) obtained from oxalic acid and sulfuric acid processing', Cellulose. Springer Netherlands, 26(15), pp. 8351-8365. doi: 10.1007/s10570-019-026909.

Jiang, J., Ye, W., Yu, J., Fan, Y., Ono, Y., Saito, T. and Isogai, A. (2018) 'Chitin nanocrystals prepared by oxidation of $\alpha$-chitin using the O2/laccase/TEMPO system', Carbohydrate Polymers, pp. 178-183. doi: 10.1016/j. carbpol.2018.01.096.

Jose, R. H. and Alfredo, D. M. E. (1999) Chitin and Chitinases. Basel, Switzerland: Birkhauser.

Jung, Y. H., Chang, T. H., Zhang, H., Yao, C., Zheng, Q., Yang, V. W., Mi, H., Kim, M., Cho, S. J., Park, D. W., Jiang, H., Lee, J., Qiu, Y., Zhou, W., Cai, Z., Gong, S. and Ma, Z. (2015) 'High-performance green flexible electronics based on biodegradable cellulose nanofibril paper', Nature Communications. Nature Publishing Group, 6(May). doi: 10.1038/ ncomms 8170 . 
Kandhola, G., Djioleu, A., Rajan, K., Labbé, N., Sakon, J., Carrier, D. J. and Kim, J. W. (2020) 'Maximizing production of cellulose nanocrystals and nanofibers from pre-extracted loblolly pine kraft pulp: a response surface approach', Bioresources and Bioprocessing. 7(1). doi: 10.1186/s40643-020-00302-0.

Kargarzadeh, H., Mariano, M., Gopakumar, D., Ahmad, I., Thomas, S., Dufresne, A., Huang, J. and Lin, N. (2018) Advances in cellulose nanomaterials, Cellulose. doi: 10.1007/s10570018-1723-5.

Kaya, M., Mujtaba, M., Ehrlich, H., Salaberria, A. M., Baran, T., Amemiya, C. T., Galli, R., Akyuz, L., Sargin, I. and Labidi, J. (2017) 'On chemistry of $\gamma$-chitin', Carbohydrate Polymers, pp. 177186. doi: 10.1016/j.carbpol.2017.08.076.

Kiruba, A., Uthayakumar, V., Munirasu, S. and Ramasubramanian, V. (2011) 'Extraction, Characterization and Physico Chemical Properties of Chitin and Chitosan from Mud Crab Shell (Scylla Serrata)', Indian Journal of Applied Research, 3(8), pp. 44-46. doi: 10.15373/2249555X/AUG2013/14.

Klemm, D., Heublein, B., Fink, H. P. and Bohn, A. (2005) 'Cellulose: Fascinating biopolymer and sustainable raw material', Angewandte Chemie - International Edition, 44(22), pp. 3358-3393. doi: 10.1002/anie.200460587.

Klemm, D., Kramer, F., Moritz, S., Lindström, T., Ankerfors, M., Gray, D. and Dorris, A. (2011) 'Nanocelluloses: A new family of nature-based materials', Angewandte Chemie - International Edition, 50(24), pp. 54385466. doi: 10.1002/anie.201001273.

Kroschwitz, J. I. (1985) Encyclopedia of Polymer Science and Engineering : Cellulose structure and properties. New York: Wiley-Interscience Publication John Wiley \& Sons.

Kurita, K., Tomita, K., Tada, T., Ishii, S., Nishimura, S. -I and Shimoda, K. (1993) 'Squid chitin as a potential alternative chitin source: Deacetylation behavior and characteristic properties', Journal of Polymer Science Part A: Polymer Chemistry, 31(2), pp. 485-491. doi: 10.1002/pola.1993.080310220.

Kurita, K., Ishii, S., Tomita, K., Nishimura, S. I. and Shimoda, K. (1994) 'Reactivity characteristics of squid $\beta$-chiti.pdf', Journal of Polymer Science, Part A: Polymer Chemistry, pp. 1027-1032.

Kusmono, Wildan, M. W. and Ilman, M. N. (2019) 'A preliminary study of extraction and characterization of nanocrystalline cellulose ( NCC ) from ramie fiber Abstract', 1, pp. 42-46.
Lahiji, R. R., Xu, X., Reifenberger, R., Raman, A., Rudie, A. and Moon, R. J. (2010) 'Atomic force microscopy characterization of cellulose nanocrystals', Langmuir, 26(6), pp. 4480-4488. doi: 10.1021/la903111j.

Lee, K. Y., Aitomäki, Y., Berglund, L. A., Oksman, K. and Bismarck, A. (2014) 'On the use of nanocellulose as reinforcement in polymer matrix composites', Composites Science and Technology. Elsevier Ltd, 105, pp. 15-27. doi: 10.1016/j.compscitech.2014.08.032.

Lemke, C. H., Dong, R. Y., Michal, C. A. and Hamad, W. Y. (2012) 'New insights into nanocrystalline cellulose structure and morphology based on solid-state NMR', Cellulose, 19(5), pp. 1619-1629. doi: 10.1007/s10570-0129759-4.

Li-rong, T., Biao, H., Wen, O., Xue-rong, C. and Yan-dan, C. (2011) 'Bioresource Technology Manufacture of cellulose nanocrystals by cation exchange resin-catalyzed hydrolysis of cellulose', Bioresource Technology. Elsevier Ltd, 102(23), pp. 10973-10977. doi: 10.1016/j.biortech.2011.09.070.

Li, D., Henschen, J. and Ek, M. (2017) 'Esterification and hydrolysis of cellulose using oxalic acid dihydrate in a solvent-free reaction suitable for preparation of surfacefunctionalised cellulose nanocrystals with high yield', Green Chemistry. Royal Society of Chemistry, 19(23), pp. 5564-5567. doi: 10.1039/c7gc02489d.

Li, F., Biagioni, P., Bollani, M., Maccagnan, A. and Piergiovanni, L. (2013) 'Multi-functional coating of cellulose nanocrystals for flexible packaging applications', Cellulose, 20(5), pp. 2491-2504. doi: 10.1007/s10570-0130015-3.

Li, W., Wang, R. and Liu, S. (2011) 'Nanocrystalline cellulose prepared from softwood kraft pulp via ultrasonic-assisted acid hydrolysis', BioResources, 6(4), pp. 4271-4281. doi: 10.15376/biores.6.4.4271-4281.

Li, Y., Liu, Yongzhuang, Chen, W., Wang, Q., Liu, Yixing, Li, J. and Yu, H. (2016) 'Facile extraction of cellulose nanocrystals from wood using ethanol and peroxide solvothermal pretreatment followed by ultrasonic nanofibrillation', Green Chemistry, 18(4), pp. 1010-1018. doi: 10.1039/ c5gc02576a.

Li, Z., Zhang, M., Cheng, D. and Yang, R. (2016) 'Preparation of silver nano-particles immobilized onto chitin nano-crystals and their application to cellulose paper for imparting antimicrobial activity', Carbohydrate Polymers. 151, pp. 834-840. doi: 10.1016/j.carbpol.2016.06.012. 
Lin, K. H., Enomae, T. and Chang, F. C. (2019) 'Cellulose Nanocrystal Isolation from Hardwood Pulp using Various Hydrolysis Conditions', Molecules, 24(20), pp. 3-5. doi: 10.3390/ molecules24203724.

Ling, Z., Edwards, J. V., Guo, Z., Prevost, N. T., Nam, S., Wu, Q., French, A. D. and Xu, F. (2019) 'Structural variations of cotton cellulose nanocrystals from deep eutectic solvent treatment: micro and nano scale', Cellulose. 26(2), pp. 861-876. doi: 10.1007/s10570-0182092-9.

Liu, Y., Wang, H., Yu, G., Yu, Q., Li, B. and $\mathrm{Mu}, \mathrm{X}$. (2014) 'A novel approach for the preparation of nanocrystalline cellulose by using phosphotungstic acid', Carbohydrate Polymers. 110, pp. 415-422. doi: 10.1016/j. carbpol.2014.04.040.

Liu, Y., Liu, M., Yang, S., Luo, B. and Zhou, C. (2018) 'Liquid Crystalline Behaviors of Chitin Nanocrystals and Their Reinforcing Effect on Natural Rubber', ACS Sustainable Chemistry and Engineering, 6(1), pp. 325-336. doi: 10.1021/acssuschemeng.7b02586.

Liu, Z., He, M., Ma, G., Yang, G. and Chen, J. (2019) 'Preparation and characterization of cellulose nanocrystals from wheat straw and corn stalk', Palpu Chongi Gisul/Journal of Korea Technical Association of the Pulp and Paper Industry, 51(2), pp. 40-48. doi: 10.7584/ JKTAPPI.2019.04.51.2.40.

Lorenz, M., Sattler, S., Reza, M., Bismarck, A. and Kontturi, E. (2017) 'Cellulose nanocrystals by acid vapour: Towards more effortless isolation of cellulose nanocrystals', Faraday Discussions. Royal Society of Chemistry, 202, pp. 315-330. doi: 10.1039/ c7fd00053g.

Lu, Q., Cai, Z., Lin, F., Tang, L., Wang, S. and Huang, B. (2016) 'Extraction of Cellulose Nanocrystals with a High Yield of $88 \%$ by Simultaneous Mechanochemical Activation and Phosphotungstic Acid Hydrolysis'. doi: 10.1021/acssuschemeng.5b01620.

Lu, Y. and Mosier, N. S. (2008) 'Kinetic modeling analysis of maleic acid-catalyzed hemicellulose hydrolysis in corn stover', Biotechnology and Bioengineering, 101(6), pp. 1170-1181. doi: 10.1002/bit.22008.

Lu, Y., Weng, L. and Zhang, L. (2004) 'Morphology and properties of soy protein isolate thermoplastics reinforced with chitin whiskers', Biomacromolecules, 5(3), pp. 1046-1051. doi: 10.1021/bm034516x.
Lu, Z., An, X., Zhang, H., Guan, M., Liu, J., Sun, Y., Nie, S., Cao, H., Lu, B. and Liu, H. (2019) 'Study on the wet-web strength and pressability of paper sheet during the press process with the addition of nano-fibrillated cellulose (NFC)', Carbohydrate Polymers. 210(29), pp. 332-338. doi: 10.1016/j.carbpol.2019.01.083.

Marchessault, R. H., Morehead, F. F. and Walter, N. M. (1959) 'Liquid Crystal Systems from Fibrillar Polysaccharides', Nature, 184, pp. 632-633. doi: 10.1038/184632a0.

Miao, J., Yu, Y., Jiang, Z. and Zhang, L. (2016) 'One-pot preparation of hydrophobic cellulose nanocrystals in an ionic liquid', Cellulose. 23(2), pp. 1209-1219. doi: 10.1007/s10570016-0864-7.

Moon, R. J., Martini, A., Nairn, J., Simonsen, J. and Youngblood, J. (2011) Cellulose nanomaterials review: Structure, properties and nanocomposites, Chemical Society Reviews. doi: $10.1039 / \mathrm{c} 0 \mathrm{cs} 00108 \mathrm{~b}$.

Morais, J. P. S., Rosa, M. D. F., De Souza Filho, M. D. S. M., Nascimento, L. D., Do Nascimento, D. M. and Cassales, A. R. (2013) 'Extraction and characterization of nanocellulose structures from raw cotton linter', Carbohydrate Polymers. 91(1), pp. 229-235. doi: 10.1016/j.carbpol.2012.08.010.

Morán, J. I., Alvarez, V. A., Cyras, V. P. and Vázquez, A. (2008) 'Extraction of cellulose and preparation of nanocellulose from sisal fibers', Cellulose, 15(1), pp. 149-159. doi: 10.1007/ s10570-007-9145-9.

Morin, A. and Dufresne, A. (2002) 'Nanocomposites of chitin whiskers from Riftia tubes and poly(caprolactone)', Macromolecules, 35(6), pp. 2190-2199. doi: 10.1021/ma011493a.

Mosier, N. S., Sarikaya, A., Ladisch, C. M. and Ladisch, M. R. (2001) 'Characterization of dicarboxylic acids for cellulose hydrolysis', Biotechnology Progress, 17(3), pp. 474-480. doi: 10.1021/bp010028u.

Ng, H. M., Sin, L. T., Tee, T. T., Bee, S. T., Hui, D., Low, C. Y. and Rahmat, A. R. (2015) 'Extraction of cellulose nanocrystals from plant sources for application as reinforcing agent in polymers', Composites Part B: Engineering, 75, pp. 176200. doi: 10.1016/j.compositesb.2015.01.008.

Nikolov, S., Petrov, M., Lymperakis, L., Friák, M., Sachs, C., Fabritius, H. O., Raabe, D. and Neugebauer, J. (2010) 'Revealing the design principles of high-performance biological composites using $\mathrm{Ab}$ initio and multiscale simulations: The example of lobster cuticle', Advanced Materials, 22(4), pp. 519-526. doi: 10.1002/adma.200902019. 
Novo, L. P., Bras, J., García, A., Belgacem, N. and Curvelo, A. A. da S. (2016) 'A study of the production of cellulose nanocrystals through subcritical water hydrolysis', Industrial Crops and Products. 93, pp. 88-95. doi: 10.1016/j. indcrop.2016.01.012.

Oun, A. A. and Rhim, J. W. (2016) 'Isolation of cellulose nanocrystals from grain straws and their use for the preparation of carboxymethyl cellulose-based nanocomposite films', Carbohydrate Polymers. 150, pp. 187-200. doi: 10.1016/j.carbpol.2016.05.020.

Oun, A. A. and Rhim, J. W. (2018) 'Effect of isolation methods of chitin nanocrystals on the properties of chitin-silver hybrid nanoparticles', Carbohydrate Polymers. 197, pp. 349-358. doi: 10.1016/j.carbpol.2018.06.033.

Oun, A. A. and Rhim, J. W. (2020) 'Preparation of multifunctional carboxymethyl cellulose-based films incorporated with chitin nanocrystal and grapefruit seed extract', International Journal of Biological Macromolecules. 152, pp. 10381046. doi: 10.1016/j.ijbiomac.2019.10.191.

Paillet, M. and Dufresne, A. (2001) 'Chitin whisker reinforced thermoplastic nanocomposites [1]', Macromolecules, 34(19), pp. 6527-6530. doi: $10.1021 / \mathrm{ma002049v}$.

Panić, V. V., Šešlija, S. I., Nešić, A. R. and Veličković, S. J. (2013) 'Adsorpcija azo boja na polimernim materijalima', Hemijska Industrija, 67(6), pp. 881-900. doi: 10.2298/HEMIND121203020P.

Peng, B. L., Dhar, N., Liu, H. L. and Tam, K. C. (2011) 'Chemistry and applications of nanocrystalline cellulose and its derivatives: A nanotechnology perspective', Canadian Journal of Chemical Engineering, 89(5), pp. 1191-1206. doi: $10.1002 /$ cjce.20554.

Perrin, E., Bizot, H., Cathala, B. and Capron, I. (2014) 'Chitin nanocrystals for pickering high internal phase emulsions', Biomacromolecules, 15(10), pp. 3766-3771. doi: 10.1021/bm5010417.

Phanthong, P., Guan, G., Ma, Y., Hao, X. and Abudula, A. (2015) 'Effect of ball milling on the production of nanocellulose using mild acid hydrolysis method', Journal of the Taiwan Institute of Chemical Engineers. pp. 617-622. doi: 10.1016/j.jtice.2015.11.001.

Phongying, S., Aiba, S. ichi and Chirachanchai, S. (2007) 'Direct chitosan nanoscaffold formation via chitin whiskers', Polymer, 48(1), pp. 393400. doi: 10.1016/j.polymer.2006.10.049.

Qiang, D., Zhang, M., Li, J., Xiu, H. and Liu, Q. (2016) 'Selective hydrolysis of cellulose for the preparation of microcrystalline cellulose by phosphotungstic acid', Cellulose. 23(2), pp. 1199-1207. doi: 10.1007/s10570-016-0858-5.
Sneeden, R. P. A. (1982) Comprehensive Organometallic Chemistry. doi: https:/doi. org/10.1016/B978-008046518-0.00107-0.

Rahman, N. H. A., Chieng, B. W., Ibrahim, N. A. and Rahman, N. A. (2017) 'Extraction and characterization of cellulose nanocrystals from tea leaf waste fibers', Polymers, 9(11), pp. 1-11. doi: 10.3390/polym9110588.

Rinaudo, M. (2006) 'Chitin and chitosan: Properties and applications', Progress in Polymer Science (Oxford), 31(7), pp. 603-632. doi: 10.1016/j. progpolymsci.2006.06.001.

Rodríguez, E. et al. (1989) 'Peat Use in Horticulture', in Peat Use in Horticulture. IntechOpen, pp. 137-144. doi: 10.5772/intechopen.69565.

Rudall, K. M. and Kenchington, W. (1973) 'the Chitin System', Biological Reviews, 48(4), pp. 597-633. doi: 10.1111/j.1469-185x.1973. tb01570.x.

Salaberria, A. M., Diaz, R. H., Labidi, J. and Fernandes, S. C. M. (2015) 'Role of chitin nanocrystals and nanofibers on physical, mechanical and functional properties in thermoplastic starch films', Food Hydrocolloids. 46, pp. 93-102. doi: 10.1016/j. foodhyd.2014.12.016.

Salaberria, A. M., Diaz, R. H., Andrés, M. A., Fernandes, S. C. M. and Labidi, J. (2017) 'The antifungal activity of functionalized chitin nanocrystals in poly (Lactid Acid) films', Materials, 10(5), pp. 1-16. doi: 10.3390/ ma10050546.

Salaberria, A. M., Labidi, J. and Fernandes, S. C. M. (2014) 'Chitin nanocrystals and nanofibers as nano-sized fillers into thermoplastic starchbased biocomposites processed by meltmixing', Chemical Engineering Journal. 256, pp. 356-364. doi: 10.1016/j.cej.2014.07.009.

Saxena, I. M. and Brown, R. M. (2005) 'Cellulose biosynthesis: Current views and evolving concepts', Annals of Botany, 96(1), pp. 9-21. doi: 10.1093/aob/mcil55.

Seabra,A. B., Bernardes, J. S., Fávaro, W. J., Paula,A. J. and Durán, N. (2018) 'Cellulose nanocrystals as carriers in medicine and their toxicities: A review', Carbohydrate Polymers. 181, pp. 514527. doi: 10.1016/j.carbpol.2017.12.014.

Seta, F. T., An, X., Liu, L., Zhang, H., Yang, J., Zhang, W., Nie, S., Yao, S., Cao, H., Xu, Q., Bu, Y. and Liu, H. (2020) 'Preparation and characterization of high yield cellulose nanocrystals (CNC) derived from ball mill pretreatment and maleic acid hydrolysis', Carbohydrate Polymers. 234, p. 115942. doi: 10.1016/j.carbpol.2020.115942. 
Shang, Z., An, X., Seta, F. T., Ma, M., Shen, M., Dai, L., Liu, H. and Ni, Y. (2019) 'Improving dispersion stability of hydrochloric acid hydrolyzed cellulose nano-crystals', Carbohydrate Polymers. 222, p. 115037. doi: 10.1016/j.carbpol.2019.115037.

Shimizu, K. I., Furukawa, H., Kobayashi, N., Itaya, Y. and Satsuma, A. (2009) 'Effects of Brønsted and Lewis acidities on activity and selectivity of heteropolyacid-based catalysts for hydrolysis of cellobiose and cellulose', Green Chemistry, 11(10), pp. 1627-1632. doi: 10.1039/b913737h.

Singh, S., Patel, M., Schwendemann, D., Zaccone, M., Geng, S., Maspoch, M. L. and Oksman, K. (2020) 'Effect of chitin nanocrystals on crystallization and properties of poly(lactic acid)-based nanocomposites', Polymers, 12(3), pp. 1-17. doi: 10.3390/polym12030726.

Siqueira, G., Bras, J. and Dufresne, A. (2010) 'Cellulosic bionanocomposites: A review of preparation, properties and applications', Polymers, 2(4), pp. 728-765. doi: 10.3390/ polym2040728.

Siró, I. and Plackett, D. (2010) 'Microfibrillated cellulose and new nanocomposite materials: a review', Cellulose, 17(3), pp. 459-494. doi: 10.1007/s 10570-010-9405-y.

Song, K., Ji, Y., Wang, L., Wei, Y. and Yu, Z. (2018) 'A green and environmental benign method to extract cellulose nanocrystal by ball mill assisted solid acid hydrolysis', Journal of Cleaner Production. 196, pp. 1169-1175. doi: 10.1016/j.jclepro.2018.06.128.

Sugiyama, J., Boisset, C., Hashimoto, M. and Watanabe, T. (1999) 'Molecular directionality of $\beta$-chitin biosynthesis', Journal of Molecular Biology, pp. 247-255. doi: 10.1006/ jmbi.1998.2458.

Sun, B., Zhang, M., Hou, Q., Liu, R., Wu, T. and Si, C. (2016) 'Further characterization of cellulose nanocrystal (CNC) preparation from sulfuric acid hydrolysis of cotton fibers', Cellulose. 23(1), pp. 439-450. doi: 10.1007/s10570-0150803-z.

Tan, X. Y., Bee, S., Hamid, A. and Lai, C. W. (2015) 'Biomass and Bioenergy Preparation of high crystallinity cellulose nanocrystals ( CNCs ) by ionic liquid solvolysis', Biomass and Bioenergy. 81, pp. 584-591. doi: 10.1016/j. biombioe.2015.08.016.

Tang, J., Sisler, J., Grishkewich, N. and Tam, K. C. (2017) 'Functionalization of cellulose nanocrystals for advanced applications', Journal of Colloid and Interface Science. 494, pp. 397409. doi: 10.1016/j.jcis.2017.01.077.
Tang, Y., Shen, X., Zhang, J., Guo, D., Kong, F. and Zhang, N. (2015) 'Extraction of cellulose nanocrystals from old corrugated container fiber using phosphoric acid and enzymatic hydrolysis followed by sonication', Carbohydrate Polymers. 125, pp. 360-366. doi: 10.1016/j. carbpol.2015.02.063.

Trache, D., Hussin, M. H., Haafiz, M. K. M. and Thakur, V. K. (2017) 'Recent progress in cellulose nanocrystals: Sources and production', Nanoscale, 9(5), pp. 1763-1786. doi: 10.1039/ c6nr09494e.

Trilokesh, C. and Uppuluri, K. B. (2019) 'Isolation and characterization of cellulose nanocrystals from jackfruit peel', Scientific Reports. 9(1), pp. 1-8. doi: 10.1038/s41598-019-53412-x.

Tzoumaki, M. V., Karefyllakis, D., Moschakis, T., Biliaderis, C. G. and Scholten, E. (2015) 'Aqueous foams stabilized by chitin nanocrystals', Soft Matter. Royal Society of Chemistry, 11(31), pp. 6245-6253. doi: 10.1039/ c5sm00720h.

Tzoumaki, M. V., Moschakis, T. and Biliaderis, C. G. (2010) 'Metastability of nematic gels made of aqueous chitin nanocrystal dispersions', Biomacromolecules, 11(1), pp. 175-181. doi: 10.1021/bm901046c.

Visanko, M., Liimatainen, H., Sirviö, J. A., Heiskanen, J. P., Niinimäki, J. and Hormi, O. (2014) 'Amphiphilic cellulose nanocrystals from acid-free oxidative treatment: Physicochemical characteristics and use as an oil-water stabilizer', Biomacromolecules, 15(7), pp. 2769-2775. doi: $10.1021 / \mathrm{bm} 500628 \mathrm{~g}$.

Visanko, M. (2015) Functionalized nanocelluloses and their use in barrier and membrane thin films. doi: 10.13140/RG.2.1.4859.9769.

Wan, A. C. A. and Tai, B. C. U. (2013) 'CHITIN A promising biomaterial for tissue engineering and stem cell technologies', Biotechnology Advances. 31(8), pp. 1776-1785. doi: 10.1016/j. biotechadv.2013.09.007.

Wang, Q. Q., Zhu, J. Y., Reiner, R. S., Verrill, S. P., Baxa, U. and Mcneil, S. E. (2012) 'Approaching zero cellulose loss in cellulose nanocrystal (CNC) production: recovery and characterization of cellulosic solid residues ( CSR ) and CNC', pp. 2033-2047. doi: 10.1007/ s10570-012-9765-6.

Wang, Q., Zhao, X. and Zhu, J. Y. (2014) 'Kinetics of strong acid hydrolysis of a bleached kraft pulp for producing cellulose nanocrystals (CNCs)', Industrial and Engineering Chemistry Research, 53(27), pp. 11007-11014. doi: 10.1021/ie501672m. 
Wang, R., Chen, L., Zhu, J. Y. and Yang, R. (2017) 'Tailored and integrated production of carboxylated cellulose nanocrystals (CNC) with nanofibrils (CNF) through maleic acid hydrolysis', ChemNanoMat, 3(5), pp. 328-335. doi: 10.1002/cnma.201700015.

Wijaya, C. J., Ismadji, S., Aparamarta, H. W. and Gunawan, S. (2019) 'Optimization of cellulose nanocrystals from bamboo shoots using Response Surface Methodology', Heliyon. 5(11), p. e02807. doi: 10.1016/j.heliyon.2019. e02807.

Xie, H., Du, H., Yang, X. and Si, C. (2018) 'Recent Strategies in Preparation of Cellulose Nanocrystals and Cellulose Nanofibrils Derived from Raw Cellulose Materials', 2018.

Xie, H., Zou, Z., Du, H., Zhang, X., Wang, X., Yang, X., Wang, H., Li, G., Li, L. and Si, C. (2019) 'Preparation of thermally stable and surfacefunctionalized cellulose nanocrystals via mixed H2SO4/Oxalic acid hydrolysis', Carbohydrate Polymers. 223, p. 115116. doi: 10.1016/j. carbpol.2019.115116.

Xu, W., Grénman, H., Liu, J., Kronlund, D., Li, B., Backman, P., Peltonen, J., Willför, S., Sundberg, A. and $\mathrm{Xu}, \mathrm{C}$. (2017) 'Mild Oxalic-Acid-Catalyzed Hydrolysis as a Novel Approach to Prepare Cellulose Nanocrystals', ChemNanoMat, 3(2), pp. 109-119. doi: 10.1002/ cnma.201600347.

Xu, Y., Salmi, J., Kloser, E., Perrin, F., Grosse, S., Denault, J. and Lau, P. C. K. (2013) 'Feasibility of nanocrystalline cellulose production by endoglucanase treatment of natural bast fibers', Industrial Crops and Products. 51, pp. 381-384. doi: 10.1016/j.indcrop.2013.09.029.

Yang, J., An, X., Liu, L., Seta, F. T., Zhang, H., Nie, S., Yao, S., Cao, H., Xu, Q., Liu, H. and Ni, Y. (2020) 'Chitin nano-crystals/sodium lignosulfonate/Ag NPs nanocomposites: a potent and green catalyst for efficient removal of organic contaminants', Cellulose. 27(9), pp. 5071-5087. doi: 10.1007/s10570-020-031612.

Yeganeh, F., Behrooz, R. and Rahimi, M. (2017) 'The effect of Sulfuric acid and Maleic acid on characteristics of nano-cellulose produced from waste office paper', International Journal of Nano Dimension, 8(3), pp. 206-215.

Younes, I. and Rinaudo, M. (2015) 'Chitin and chitosan preparation from marine sources. Structure, properties and applications', Marine Drugs, 13(3), pp. 1133-1174. doi: 10.3390/ md13031133.
Yu, H., Qin, Z., Liang, B., Liu, N., Zhou, Z. and Chen, L. (2013) 'Facile extraction of thermally stable cellulose nanocrystals with a high yield of $93 \%$ through hydrochloric acid hydrolysis under hydrothermal conditions', Journal of Materials Chemistry A, 1(12), pp. 3938-3944. doi: $10.1039 / \mathrm{c} 3 \mathrm{ta} 01150 \mathrm{j}$.

Yu, H., Abdalkarim, S. Y. H., Zhang, H., Wang, C. and Tam, K. C. (2019) 'Simple Process to Produce High-Yield Cellulose Nanocrystals Using Recyclable Citric/Hydrochloric Acids', ACS Sustainable Chemistry and Engineering. American Chemical Society, 7(5), pp. 49124923. doi: 10.1021/acssuschemeng.8b05526.

Yu, H. Y., Zhang, D. Z., Lu, F. F. and Yao, J. (2016) 'New Approach for Single-Step Extraction of Carboxylated Cellulose Nanocrystals for Their Use As Adsorbents and Flocculants', ACS Sustainable Chemistry and Engineering, pp. 2632-2643. doi: 10.1021/ acssuschemeng.6b00126.

Yu, M., Yang, R., Huang, L., Cao, X., Yang, F. and Liu, D. (2012) 'Preparation and characterization of bamboo nanocrystalline cellulose', BioResources, 7(2), pp. 1802-1812. doi: 10.15376/biores.7.2.1802-1812.

Yuan, Y., Hong, S., Lian, H., Zhang, K. and Liimatainen, H. (2020) 'Comparison of acidic deep eutectic solvents in production of chitin nanocrystals', Carbohydrate Polymers. 236, p. 116095. doi: 10.1016/j.carbpol.2020.116095.

Zeng, J. B., He, Y. S., Li, S. L. and Wang, Y. Z. (2012) 'Chitin whiskers: An overview', Biomacromolecules, 13(1), pp. 1-11. doi: 10.1021/bm201564a.

Zhang, L., Tsuzuki, T. and Wang, X. (2015) 'Preparation of cellulose nanofiber from softwood pulp by ball milling'. doi: $10.1007 /$ s10570-015-0582-6.

Zhang, P. P., Tong, D. S., Lin, C. X., Yang, H. M., Zhong, Z. K., Yu, W. H., Wang, H. and Zhou, C. H. (2014) 'Effects of acid treatments on bamboo cellulose nanocrystals', ASIA-PACIFIC JOURNAL OF CHEMICAL ENGINEERING. doi: 10.1002/apj.1812.

Zhao, Y., Zhang, Y., Lindström, M. E. and Li, J. (2015) 'Tunicate cellulose nanocrystals: Preparation, neat films and nanocomposite films with glucomannans', Carbohydrate Polymers. 117, pp. 286-296. doi: 10.1016/j. carbpol.2014.09.020. 